\title{
A Diagnostic and Policy Options for the Vocational Education and Training System in Belarus
}

\author{
June 2021 \\ Education Global Practice \\ Europe and Central Asia
}

The World Bank 


\section{ACKNOWLEDGEMENTS}

The preparation of this report was led by Rafael E. de Hoyos Navarro, with valuable inputs from Flora Kelmendi, Viktor Rudakov, Sviatlana Sous, Lucy Kruske, and James Gresham. The report was also informed by feedback from Denis Nikolaev, Pavel Fountikov, Tigran Shmis and Veranika Adamchuk.

The work was carried out under the overall supervision of Alexander Kremer, Country Manager for Belarus, and Harry Patrinos, Practice Manager for Education in Europe and Central Asia. Valuable comments were received from Michael Weber, Koji Miyamoto and Nobuyuki Tanaka.

Special thanks are given to the Belarus Ministry of Education and the Republican Institute for Vocational Education (RIPO) who provided information and data to the team. 


\section{Contents}

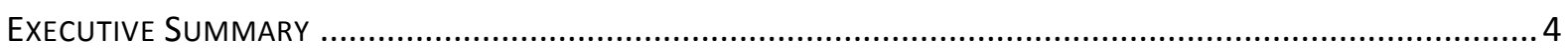

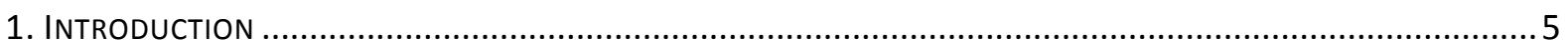

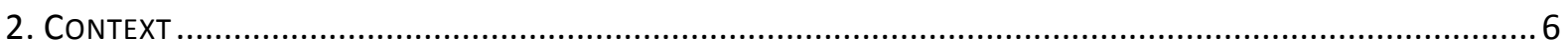

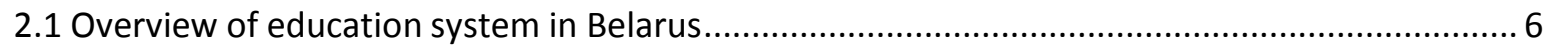

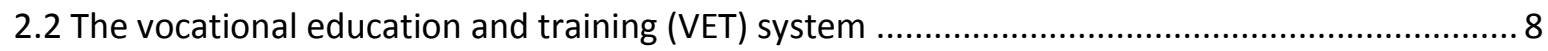

2.3 Recent trends in education attainment among the working age population ........................... 13

2.4 Macroeconomic and labor market trends in Belarus .............................................................. 15

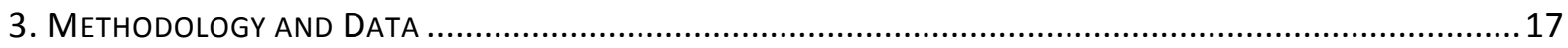

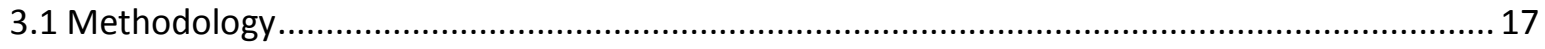

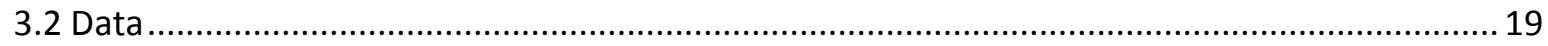

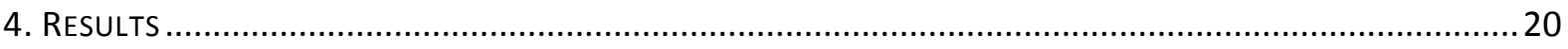

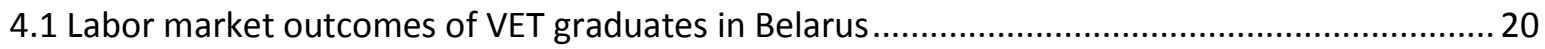

4.2 Learning outcomes and socioeconomic background of VET students ..................................... 24

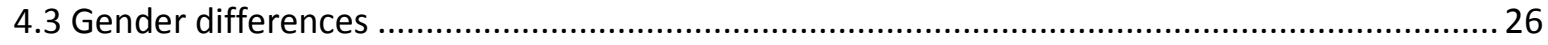

4.4 Interpretation of labor market outcomes of VET education ..................................................... 27

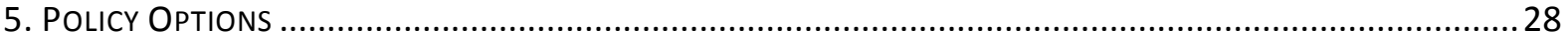

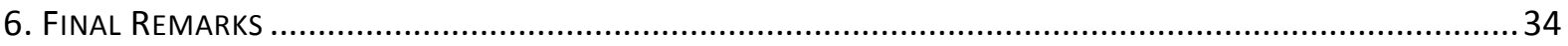

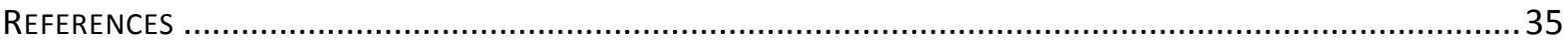

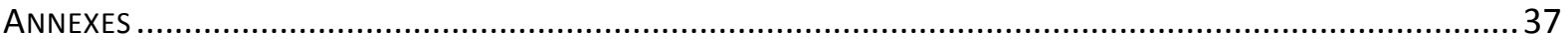




\section{EXECUTIVE SUMMARY}

The objective of this report is to assess the effectiveness of the vocational education and training (VET) system in Belarus and provide policy recommendations for improvements of the system. Labor force survey data are used to estimate the returns to vocational education, distinguishing between the two existing education options within the vocational system: Vocational-Technical (VT) and Secondary Specialized Education (SSE). The labor market analysis is complemented with descriptive statistics from the Programme for International Student Assessment (PISA) 2018 to identify the socioeconomic background and learning outcomes of VET students compared to students in the general education track.

Results indicate that the labor market outcomes of the VET system in Belarus are positive, but there are large heterogeneities between the two VET options. Graduates of SSE have a 13 percent wage premium compared with workers with a general secondary education diploma, while graduates of VT show more modest returns, and declining over time. The returns to VT are less than 5 percent, and among young workers (ages 23 to 25), statistically speaking, VT does not provide a positive wage premium over a secondary education diploma. Perhaps more concerning, VT graduates are more vulnerable to macroeconomic shocks, experiencing sharper declines in wages in relation to secondary education graduates, making the returns to VT negative during times of economic contraction.

The low returns to VET, particularly VT education in Belarus, could be related to the following factors: (a) adverse selection of students from poor socioeconomic backgrounds to VET; (b) low levels of basic cognitive skills, numeracy and literacy among VET students; (c) use of outdated equipment and an antiquated curriculum in VT education; and (d) a weak relationship between the VT system and the demands from employers, especially the private sector which results in a supply of skills in the VET sector that does not match the labor market demand.

VET students tend to come from more disadvantaged households with lower parental education, household assets and incomes. Not surprisingly given differences in socioeconomic levels, VET students have significantly lower PISA scores in mathematics, reading and science compared to students in the general track; these differences are equivalent to more than one year of formal schooling. Taken together, the low returns to VET, particularly VT, and the large share of low-income students getting a vocational diploma, calls for the urgent need to implement reforms to improve the quality and labor market relevance of the vocational education and training system in Belarus.

Based on the VET system constraints and international best practices, the World Bank identifies five broad policy options, aimed at improving and strengthening the relevance and quality of the VET systems as well as promoting more equitable learning outcomes:

1. Upgrade VET facilities and equipment.

2. Strengthen employer engagement.

3. Advance teacher professional development.

4. Collect and use data on labor market outcomes.

5. Improve foundational skills of VET students. 


\section{INTRODUCTION}

The COVID-19 pandemic uncovered and exacerbated preexisting inequalities, exposing the limitations of the public systems responsible for human capital formation. More than ever, human capital must be at center of the recovery process in Belarus. Education systems need to guarantee the necessary skills to the entire student population, particularly among disadvantaged groups. Given that a great majority of disadvantaged students enroll in the vocational education and training (VET) system in Belarus, it is critical that the education system is up-to-date in terms of its pedagogical methods, equipment, and facilities, and maintains a constant interaction with the private sector to anticipate to labor market demands.

In Belarus and beyond, VET has traditionally been a direct route preparing secondary school graduates for the labor market in an applied and practical manner. Changes in industry structure, automatization and challenges for state-owned enterprises have posed problems to the sector across Central and Eastern Europe. Previous international analytical work indicates several challenges to the development of the Belarusian VET system.

While the unemployment rate in Belarus is low (4.2 percent in 2019), the latest BEEPS survey shows that $\mathbf{1 1 . 9}$ percent of Belarus firms identify an inadequately educated workforce as a major constraint (6.4 percent for ECA and 7.4 for UMICs), and skills have appeared in the top 3 constraints in the last 3 rounds of BEEPS. For medium and large size firms this share becomes bigger than 22.8 percent, and for firms located in specific regions even more than 31 percent. This indicates that quality and relevance of provision are a problem.

The results presented in this report show that the efficiency of the VET sector is low and demographic changes open the opportunity to reform and modernize the VET system. During the last decade, the number of VET students decreased by one third, while the number of institutions and staff (especially in SSE) has seen little change. Moreover, the existing VET network was designed for a much bigger number of students and was not rationalized in line with demographic decline. In addition, the geographical composition of the VET network was guided mainly by student location and not so much oriented to the industries and labor market needs. The prevalence of the VET institutions is therefore more on the rural side of the country. Therefore, this becomes an operation targeted on the most vulnerable populations. Current financing of the VET system is still based on tradition/negotiations and not on the transparent per capita formula used already on other levels of national education. Performance indicators are also lacking in the financing mechanism. The returns to education in Belarus show a significant difference between VET and Higher Education. Given the size of enrollment in VET, the reform of this sector therefore has a significant potential for boosting economic growth while promoting social mobility.

The objective of this report is to assess the effectiveness of the VET system in Belarus and derive policy recommendations for improvements of the system from international best practices. The report primarily analyzes household survey data to estimate the returns to education of VET, distinguishing between the two VET tracks in Belarus. This labor market analysis is further complemented with descriptive statistics from the Programme for International Student Assessment (PISA) 2018, which helped to identify the socioeconomic 
background and learning outcomes of VET students compared to students in the general education track.

This report contributes to the scarce literature on labor market outcomes of different levels of education and returns to education in Belarus. Previous calculations of returns to education in Belarus were carried out for 1996-2001 (Pastore and Verashchagina 2006) and for 19952011 (Chubrik 2013). Unlike previous studies that emphasized higher education, this analysis concentrates on returns to VET. The report shows patterns of returns to education that are consistent with previous studies for Belarus and recent estimates for Russia (Melianova and others 2020). The results from Russia are particularly relevant given the institutional similarities between Russia and Belarus.

The report is structured as follows. Section 2 presents an overview of education and the VET system, along with recent macroeconomic, education and labor market trends in Belarus. Section 3 describes the data and methodology used for the analysis. Section 4 provides the main results of the World Bank's analysis of the labor market outcomes of VET graduates compared to graduates of other educational programs. It also includes analysis of the socioeconomic status of VET compared to general education students. Finally, section 5 offers policy recommendations for the improvement of VET system in Belarus while section 6 concludes the report with concluding remarks.

\section{CONTEXT}

\subsection{Overview of education system in Belarus}

The education system of Belarus consists of four main levels of education (attainment): preschool, primary, secondary, and higher education (summarized in Figure 1). Primary education starts at age 6 and lasts 4 years. Basic education, which is equivalent to lower secondary in other countries, lasts 5 years and can be followed by 2 more years of general education (grades 10 and 11), leading to general secondary education certificate. Alternatively, students can enroll in a lyceum after primary school which covers the entire middle school within the general track. Students graduating from lower secondary can opt for a vocational school, instead of the upper secondary general track in either a vocational technical school or a specialized secondary institution which varies in extension (from 2 to 5 years). Higher education lasts 4 to 6 years, and postgraduate education is the highest education level. Education for students with disabilities is provided as specialized education at all pre-tertiary educational levels. Students with disabilities can also supplement their education by pursuing learning opportunities outside of the formal education system at all levels of education. 
Figure 1 Overview on the Education System in Belarus

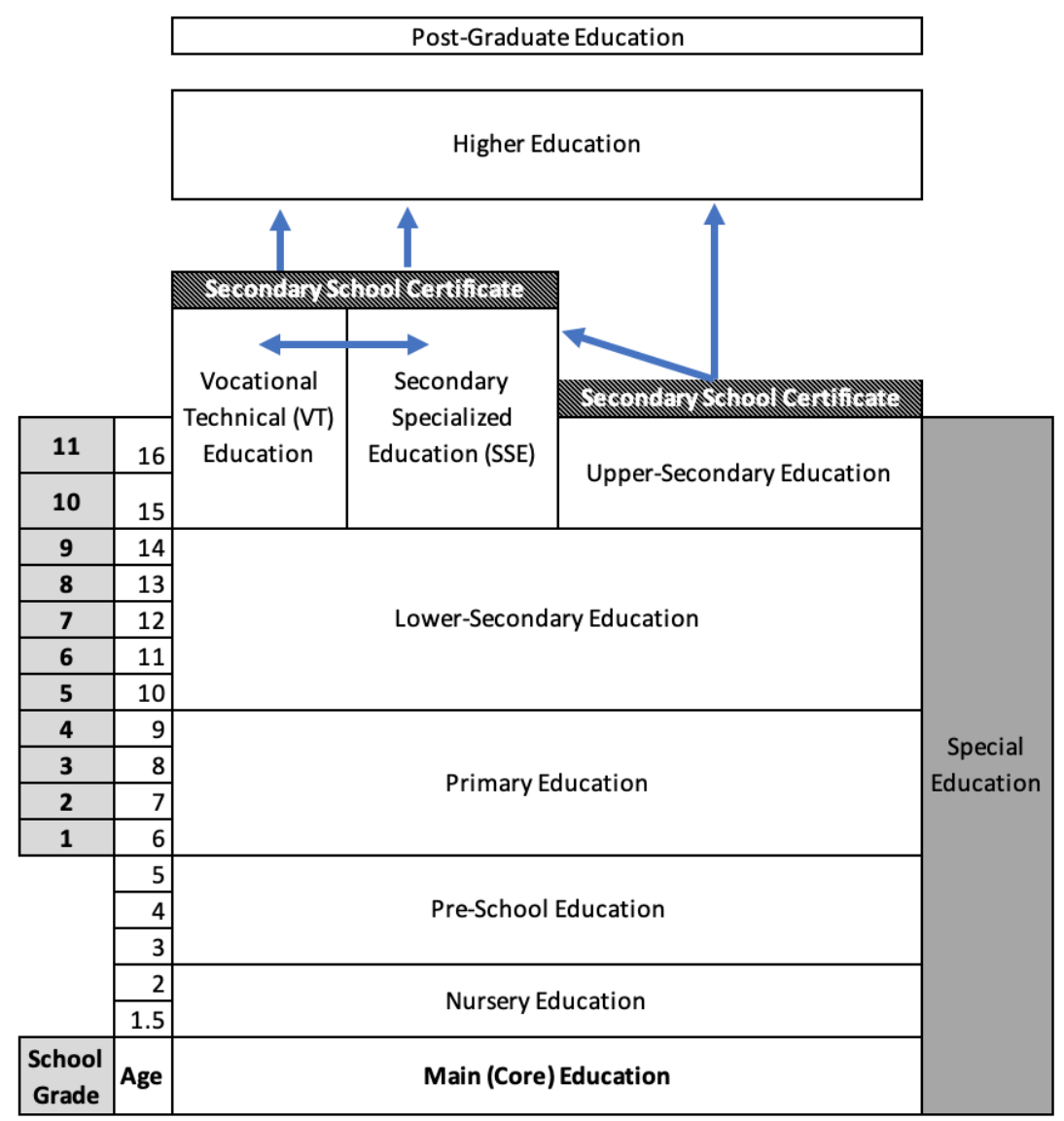

Source: Author's own information based on the Ministry of Education.

Over the last decade, the number of students in both vocational and secondary specialized education and higher education has been declining, largely due to demographic changes. In 2020 there were more than 1 million students enrolled in more than 3,000 institutions providing primary, basic, and general secondary education services. The latest figures available from the Belarus National Statistical Committee show that in the academic year 2019-2020, more than 65,000 students obtained general secondary certificate, 28,000 got a vocation technical degree and 33,2000 graduated with a secondary specialized diploma. Graduation rates in the three secondary education options (general, vocational technical and specialized) are very high with slightly higher dropouts in secondary specialized education. After completing general secondary education, 55 percent of graduates continued their studies in higher education, 25 percent opted for a specialized secondary education and 17 percent enroll in a vocational technical school (European Training Foundation 2020a).

The learning outcomes in Belarus are high in accordance with the country's level of development (Figure 2). In the Programme for International Student Assessment (PISA), Belarus ranks 39 out of 79 countries in mathematics (above Russia and between the US and Malta, 15-year-olds in Belarus score 472 points compared to an average of 489 points in OECD countries), it ranks 38 out of 79 countries in sciences (between Ukraine and Croatia, 15-yearolds in Belarus score 471 points, compared to an average of 489 points), and 37 out of 79 in reading (between Iceland and Israel, 15-year-olds in Belarus score 474 points compared to an 
OECD average of 487 points) (OECD 2018). While overall learning outcomes are high, inequality in education outcomes based on socioeconomic factors is indicated. Data show education for students from lower socioeconomic category and rural areas lagging their peers in higher income quintile and urban areas.

Figure 2 PISA reading scores and GDP per capita

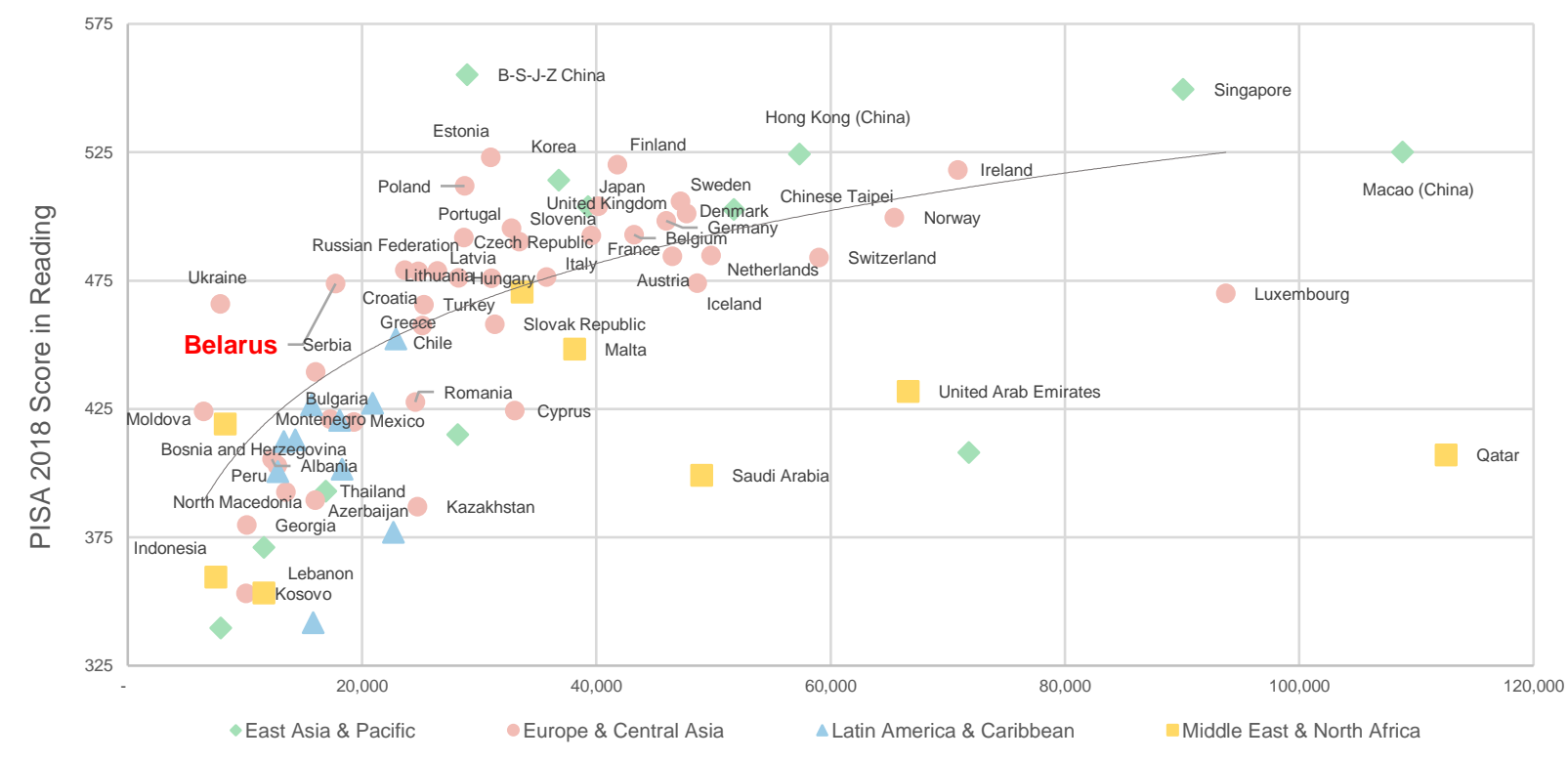

Source: OECD 2018

\subsection{The vocational education and training (VET) system}

The vocational education and training (VET) system in Belarus consist of two options yielding different qualifications:

a. Vocational technical (VT). This option has a duration of 1 to 3 years. It is recognized as an International Standard Classification of Education (ISCED) level 4 (postsecondary nontertiary education).

b. Secondary specialized education (SSE). This option has a duration of 2 to 4 years. It can be recognized as ISCED level 3 (upper secondary education), ISCED level 4 (postsecondary nontertiary education), or ISCED level 5 (short-cycle tertiary education). 
Table 1: Key Characteristics of Vocational Technical Education and Secondary Specialized Education

\section{Vocational Technical}

(VT)
Secondary Specialized Education (SSE)

\begin{tabular}{|c|c|c|}
\hline Entry Point & $\begin{array}{ll}\text { - } & \text { Grade } 10(70 \%) \\
\text { - } & \text { Secondary School Certificate } \\
(30 \%)\end{array}$ & $\begin{array}{ll}\text { - } & \text { Grade } 10(47 \%) \\
\text { - } & \text { Secondary School Certificate } \\
& (37 \%) \\
\text { - } & \text { VT Certificate }(16 \%)\end{array}$ \\
\hline Duration & $1-3$ years & $2-4$ years \\
\hline Qualifications & $\begin{array}{l}\text { VT Certificate } \\
\text { Secondary School Certificate } \\
\text { optional, requires additional } \\
\text { study time }\end{array}$ & $\begin{array}{l}\text { SSE Certificate } \\
\text { Secondary School Certificate } \\
\text { optional, requires additional } \\
\text { study time }\end{array}$ \\
\hline $\begin{array}{l}\text { International } \\
\text { Standard } \\
\text { Classification of } \\
\text { Education (ISCED) }\end{array}$ & $\begin{array}{l}\text { ISCED Level 4: Postsecondary } \\
\text { nontertiary education }\end{array}$ & $\begin{array}{l}\text { ISCED Level 3: Upper secondary } \\
\text { education } \\
\text { ISCED Level 4: Postsecondary } \\
\text { nontertiary education } \\
\text { ISCED Level 5: Short-cycle tertiary } \\
\text { education }\end{array}$ \\
\hline $\begin{array}{l}\text { Pathway into } \\
\text { general } \\
\text { education } \\
\end{array}$ & $\begin{array}{l}\text { Earn Secondary School Certificate } \\
\text { while enrolled in VT }\end{array}$ & $\begin{array}{l}\text { Earn Secondary School Certificate } \\
\text { while enrolled in SSE }\end{array}$ \\
\hline $\begin{array}{l}\text { Pathway into } \\
\text { higher education }\end{array}$ & $\begin{array}{l}\text { Possible } \\
\text { Secondary School Certificate, } \\
\text { additional exams required for } \\
\text { programs outside of professional } \\
\text { concentration }\end{array}$ & $\begin{array}{l}\text { Possible } \\
\text { Secondary School Certificate, } \\
\text { additional exams required for } \\
\text { programs outside of professional } \\
\text { concentration }\end{array}$ \\
\hline $\begin{array}{l}\text { Professional } \\
\text { outlook }\end{array}$ & Blue-collar professions & White-collar professions \\
\hline $\begin{array}{l}\text { Number of } \\
\text { graduates }\end{array}$ & 28,000 & 33,200 \\
\hline $\begin{array}{l}\text { Pursued pathway } \\
\text { after graduation }\end{array}$ & $\begin{array}{l}85 \% \text { employment } \\
12 \% \text { SSE or higher education } \\
0.7 \% \text { military service } \\
0.07 \% \text { self-employment }\end{array}$ & No data available \\
\hline
\end{tabular}


After graduating from basic education (completion of grade 9), students can join vocational education or general secondary education or pursue a combined general secondary education with vocational degree. VET graduates that completed the general secondary education are eligible to pursue higher education. VT and SSE graduates with a general secondary diploma have direct access to higher education in the fields related to their previous area of study through a simplified admission procedure, consisting of an interview and an exam in a field-related area of study. If VET graduates want to study at the higher education level in an area different from their previous area of study, they have to take a centrally administered, standardized admission examination, which assesses three subjects areas (Russian, mathematics, and a field-related subject for that new area of study). For students who enrolled in vocational directly after graduating from basic education, higher education is not an option, unless they go back to complete the courses needed to get an upper secondary diploma. ${ }^{1}$

The duration of studies at a VT school may vary from 1 to 3 years, depending on when the enrollment occurs and whether an applicant intends to obtain, simultaneously, a labor market certificate and a general / upper secondary education diploma. VT education provides graduates with a certificate and prepares students for blue-collar professions, such as craft worker, skilled agricultural worker, plant and machine operator, among others (see Figure 3). According to Churko and Milevich (2020), during the academic year 2020, 70 percent of the students admitted to VT came directly from basic education (grade 9) and the rest had already a general secondary education degree (grade 11).

A second option of vocational education is SSE. Students may enroll in this option after finishing basic education or graduating from general secondary education (completion of grade 11). Students can also enroll after graduating from vocational technical education. While duration of studies differs by specialization, type of institution, and pathway of enrollment, it typically requires 2-4 years of study after general secondary education or 1-3 years after finishing VT education. Secondary specialized education is expected to prepare students to become mid-level specialists for mainly white-collar jobs. This type of vocational education is the most common one for the workforce in Belarus, producing technicians, associate professionals, clerical and support staff, as well as services and sales workers (see Figure 3). During the academic year 2020, 47 percent of the students admitted to SSE came directly from basic education (grade 9), 37 percent had already a general secondary education degree (grade 11) and the remaining 16 percent had a VT degree prior to entering SSE (Palushkina P.A., 2020).

\footnotetext{
${ }^{1}$ Another important factor that may affect pathways of students is military service. Military service is compulsory in Belarus for men ages 18-27. They must serve for 18 months, or 12 months for higher education graduates.
} 
Figure 3 Occupational structure of workers by level of education

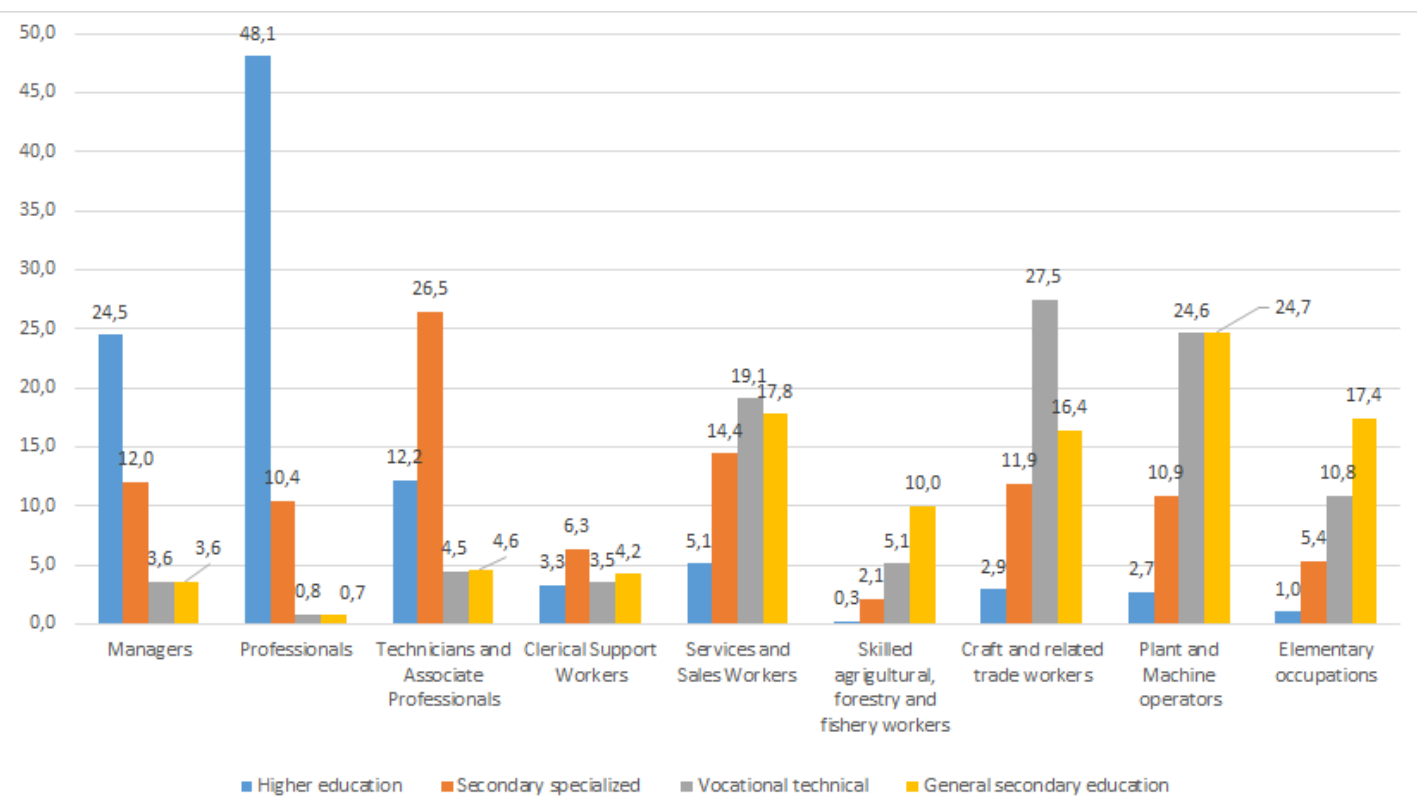

Source: Author's calculations based on data from the labor force survey, 2012-2019. National Statistical Committee of the Republic of Belarus.

In 2020-2021, there were 176 vocational technical (VT) schools and 224 secondary specialized education (SSE) institutions in Belarus. Most of the VET institutions, VT and SSE, in Belarus are public while only 3 VT schools and 13 SSE schools are private. This means less than 5 percent of VET institutions in Belarus are private (Table 2). The number of students who enter VT schools is almost twice as high as those who enter into SSE (Table 2). The student per faculty ratio is higher in SSE.

Table 2 Main indicators of the VET sector in Belarus in 2020

\begin{tabular}{|l|c|c|}
\hline Indicator & $\begin{array}{c}\text { Vocational } \\
\text { technical } \\
\text { education }\end{array}$ & $\begin{array}{c}\text { Secondary } \\
\text { specialized } \\
\text { education }\end{array}$ \\
\hline Number of institutions & 176.0 & 224.0 \\
\hline Number of private institutions & 3.0 & 13.0 \\
\hline Number of students, x1000 & 63.4 & 112.5 \\
\hline Number of state-funded students, x1000 & $\mathrm{N} / \mathrm{A}$ & 72.9 \\
\hline $\begin{array}{l}\text { Number of students, studying on a fee basis, } \\
\text { x1000 }\end{array}$ & $\mathrm{N} / \mathrm{A}$ & 39.6 \\
\hline $\begin{array}{l}\text { Number of students, studying in private } \\
\text { institutions, } x 1000\end{array}$ & $\mathrm{~N} / \mathrm{A}$ & 9.9 \\
\hline Yearly enrollment, x1000 & 28.4 & 38.1 \\
\hline Graduates, $x 1000$ & 28.0 & 33.2 \\
\hline Number of faculty (staff), $x 1000$ & 7.0 & 9.6 \\
\hline Student per faculty ratio & 9.1 & 11.7 \\
\hline
\end{tabular}

Sources: National Statistical Committee of Belarus 2011-2019; Education in the Republic of Belarus 2020. 
VET institutions charge tuition fees. Students have the option to pay tuition fees or enter into a contract with the government or a (primarily public) employer who covers tuition fees in exchange for a commitment to work for a specific employer for a specified period time after graduation. Among SSE students, 65 percent receive funding from the state, while 35 percent are self-funded (fee-basis). The details of such work-placement system are defined by the Code on Education of the Republic of Belarus. Most students choose to enter into agreements with the government or employers to fund their VET education. Students who did not enter into any contractual obligations can voluntarily participate in the work-placement system after graduation and often seek support from their education institutions to grant them a work-placement, if places remain available.

Government-funded students are assigned to an enterprise, company, or organization by their education institution upon graduation. The mandatory duration of a work-placement is typically one year for VT graduates and two years for SSE graduates. Some students have funding from the national government or local authorities, a funding mechanism called целевая подготовка, or targeted education and training. These students can commit to a mandatory work placement for two years, if they are VT graduates, and for three years, if they are SSE graduates. The duration of mandatory work is determined by the contracts signed between an employer and the student.

The main distribution of VET graduates is shown in Table 3. Most graduates under the placement system are employed by public enterprises in fields that directly relate to their study program. In the 2019 cohort, 24,500 out of a total of 28,000 VT graduates (that is, 88.0 percent) were subject to the mandatory job placement system and 72.0 percent ended up in a job assigned to them. In contrast, less than 0.5 percent of them could find jobs independently. In the case of SSE, a lower share of graduates went through the mandatory job placement (56.3 percent). The difference in the share of mandatory job placement between VT and SSE graduates is explained by a higher share of student in SSE who study on a fee-basis (see Table 2).

Table 3 Indicators of VET graduate distribution system in Belarus

\begin{tabular}{|c|c|c|c|c|}
\hline \multirow[b]{2}{*}{ Indicators } & \multicolumn{2}{|c|}{ Vocational technical school } & \multicolumn{2}{|c|}{$\begin{array}{c}\text { Secondary specialized } \\
\text { education }\end{array}$} \\
\hline & $\begin{array}{l}\text { Number, } \\
\text { thousands }\end{array}$ & Share & $\begin{array}{l}\text { Number, } \\
\text { thousands }\end{array}$ & Share \\
\hline Graduates & 28 & $100.0 \%$ & 33.2 & $100.0 \%$ \\
\hline $\begin{array}{l}\text { Graduates involved in the } \\
\text { mandatory job placement } \\
\text { system }\end{array}$ & 24.5 & $88.0 \%$ & 18.7 & $56.3 \%$ \\
\hline $\begin{array}{l}\text { Got a job according to the } \\
\text { placement system }\end{array}$ & 20.1 & $72.0 \%$ & 18.6 & $56.0 \%$ \\
\hline $\begin{array}{l}\text { Got the right to find job } \\
\text { independently }\end{array}$ & 0.1 & $0.4 \%$ & 0.1 & $0.3 \%$ \\
\hline
\end{tabular}

Sources: Authors' calculations based on data from the National Statistical Committee of Belarus 2011-2019 and Education in the Republic of Belarus 2020. 
Belarus introduced a new mechanism of interaction between the supply and demand of skills, namely, Sectoral Councils for Qualifications. Currently, 15 Sectoral Councils for Qualifications are established and function in Belarus created under the various public administration bodies (see Figure 4).

Figure 4: Sectoral Councils for Qualifications

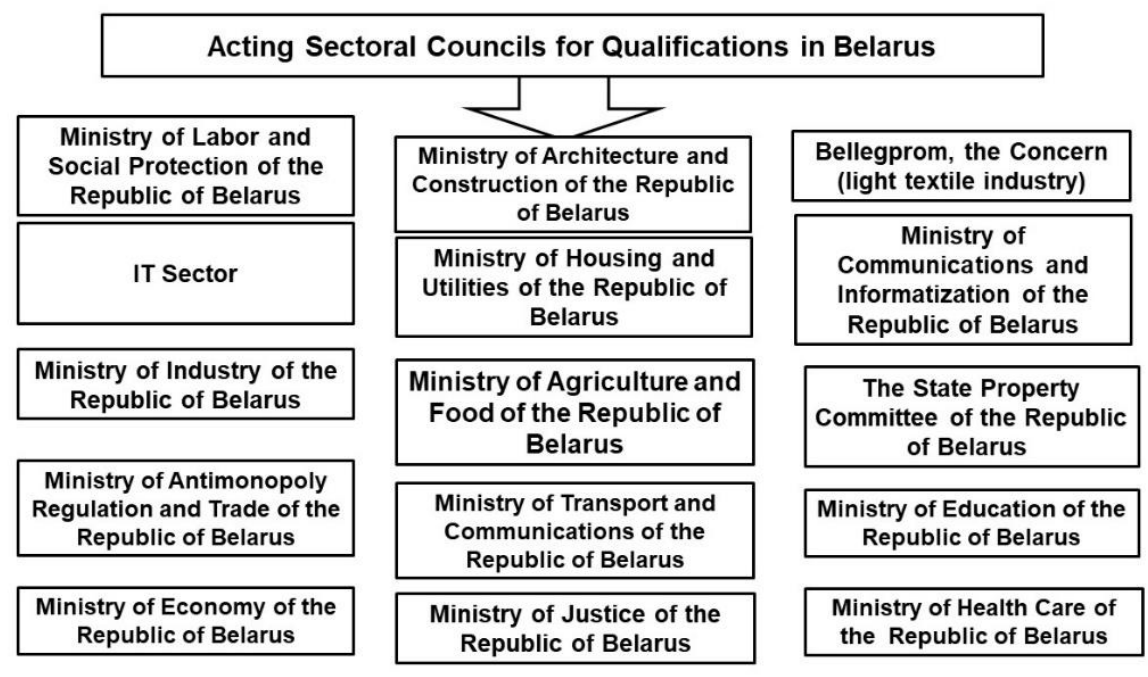

Engagement and participation of the representatives of the VET system in the Sectoral Councils for Qualifications aims to improve the National Qualification framework (NQF). The key role of such councils is to ensure education and training aligned with labor market needs. Under their mandates, Sectoral Councils for Qualifications (SCQ) are have the attribution to monitoring labor market demands, define the relevant vocational qualifications, define the education and training curriculum based on labor market needs, initiate a dialogue with the stakeholders to exchange views about skills demands, take decisions on the developments and amendments to the professional standards, among others.

The SCQ is formed by a representative of the Ministry of Labor and Social Protection, the Ministry of Education, other state bodies, local executive and administrative bodies, trade unions, and employers (associations of employers). Belarus holds the approach that occupational standards should be a foundation for the curriculum development and update.

\subsection{Recent trends in education attainment among the working age population}

Most of the working age population in Belarus have attained a higher education degree, such as in technical vocational education, secondary specialized education, or postsecondary education. In the last decade, the share of the population holding a higher education degree increased considerably from 21 percent in 2011 to 29 percent in 2019. The share of the population with secondary specialized education has remained relatively stable, while the share with vocational education has decreased from 21 percent to 13 percent during the same period (Figure 5). 
Figure 5 Working-age population by education level (2011-2019) (\%)

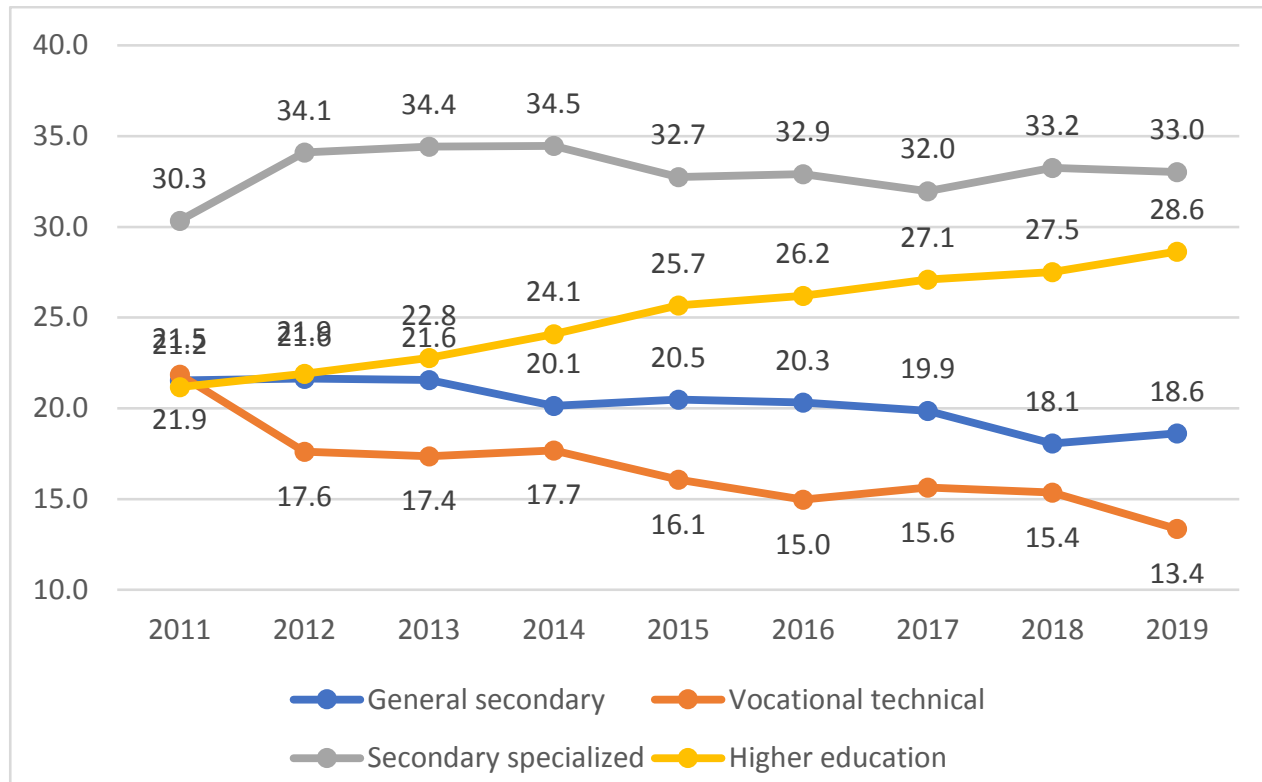

Source: Authors' calculations based on data from the National Statistical Committee of Belarus 2011-2019.

The trends shown in Figure $\mathbf{5}$ are magnified for the cohort ages $\mathbf{2 3}$ to $\mathbf{3 5}$ years. ${ }^{2}$ During the past decade, the share of higher education graduates among the Belarusian youth population increased dramatically from 28 percent to 43 percent, while the share of youth holding a vocational degree decreased from 22 percent to 11 percent. The share of workers with a secondary specialized degree remained stable (Figure 6). The recent trends in education attainment of the labor force, particularly those among younger cohorts show that the demand for vocation education is in a long-term negative trend.

Figure 6 Population ages 23 to 35 years by education level (2011-2019) (\%)

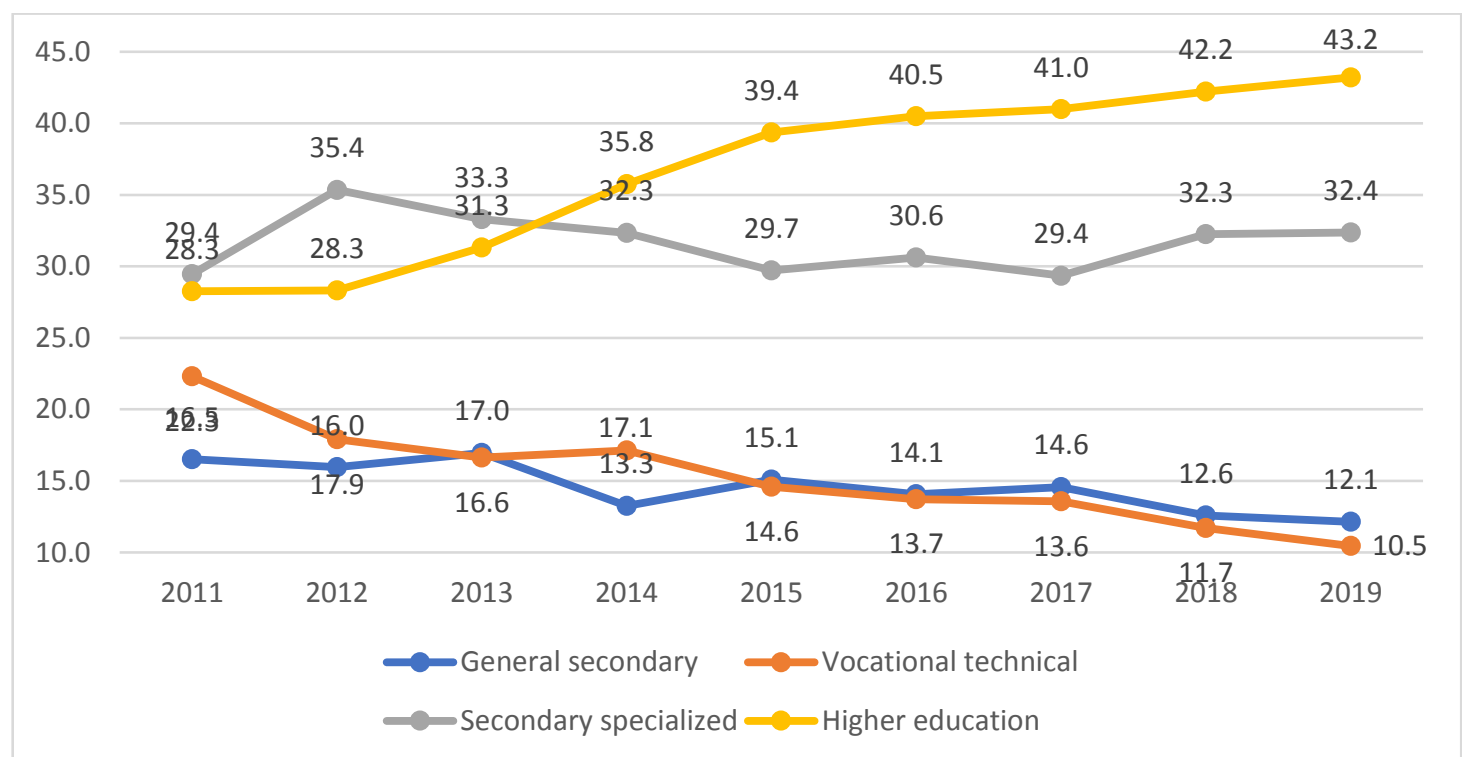

Source: Authors' calculations based on data from the National Statistical Committee of Belarus (2011-2019).

\footnotetext{
${ }^{2}$ The lower bound of this cohort was chosen at age 23 since it is the expected age of graduation from higher education in Belarus.
} 
The analysis of employment status by educational level shows that higher education and VET graduates have considerably higher chances to be employed and lower probability of being out of the labor force compared to secondary education graduates. More than $90 \%$ of higher education graduates and around $85 \%$ of VET graduates are employed, while employment level of secondary education and lower levels of education graduates is considerably lower (Figure 6). Unemployment level is lowest among higher education and secondary specialized education graduates, while it is higher among vocational school (5.4\%) and secondary education (6\%) graduates. A higher rate of labor participation among VET graduates could be associated with gender imbalances since 70 percent of vocational education students are male.

Figure 7: Employment status by education attainment, 2019

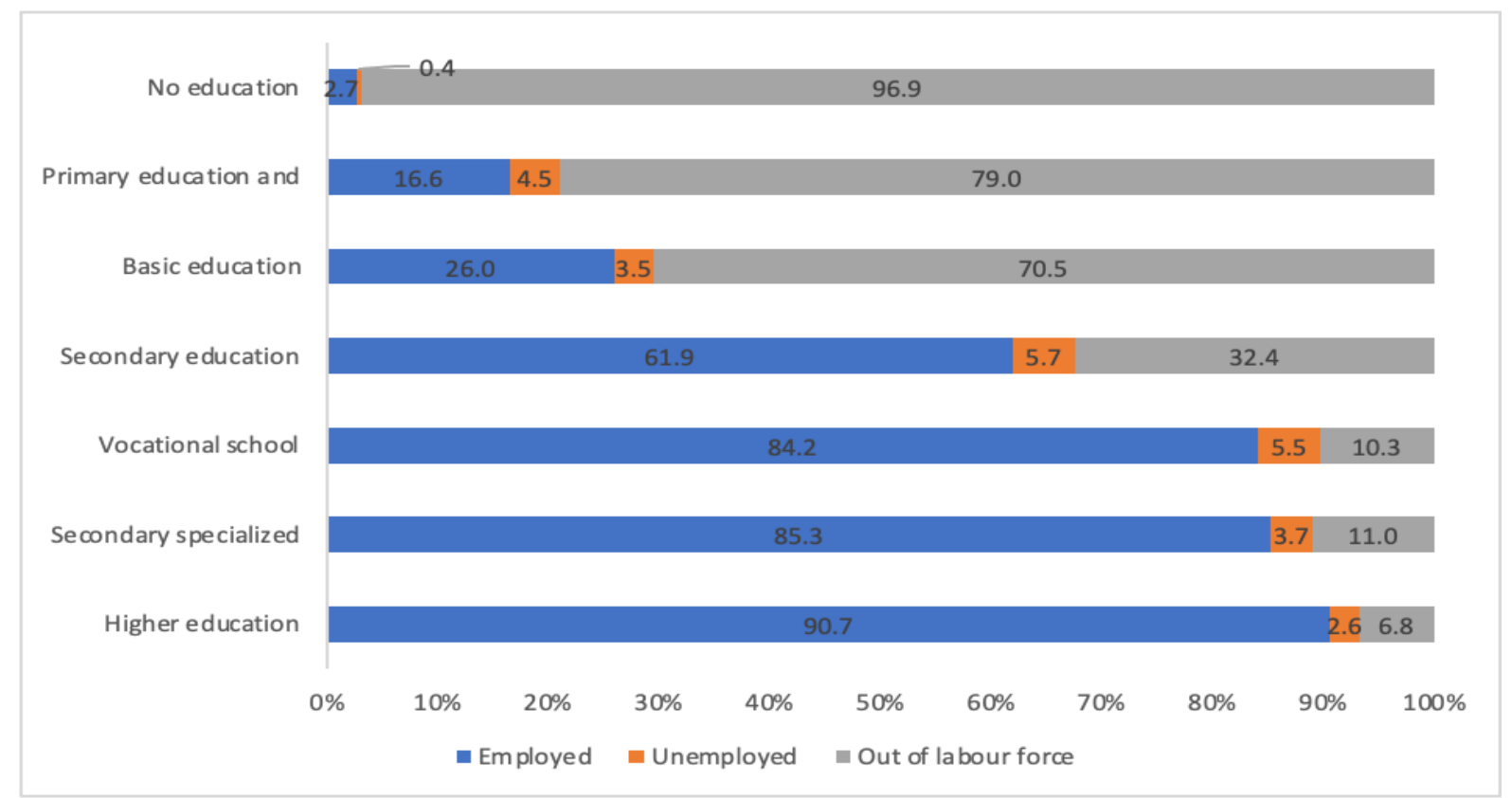

Source: Authors' calculations based on data from the National Statistical Committee of Belarus (2019).

\subsection{Macroeconomic and labor market trends in Belarus}

GDP per capita grew from US\$5,351 in 2009 to US\$6,663 in 2019 showing a positive trend except for the period 2014-2016 when it suffered a significant contraction (Figure 8). Between 2009 and 2014 GDP per capita grew considerably as the economy bounced back from the global financial crisis of 2008-2009, but between 2014-2016 there was a sharp decline, caused by the economic recession in Russia. By 2019 GDP per capita had not reached the precrisis levels shown in 2014. During that time, the Belarussian economy was characterized by high inflation rate, especially in 2011 and 2012, when prices increased at an annualized rate above 50 percent per year. But the inflation rate has been declining since 2013 to reach a comfortable rate of 6 percent in 2019 (Figure 8). 
Figure 8 GDP per capita, current US dollars (left panel) and inflation rate, (\%) (right panel) in Belarus

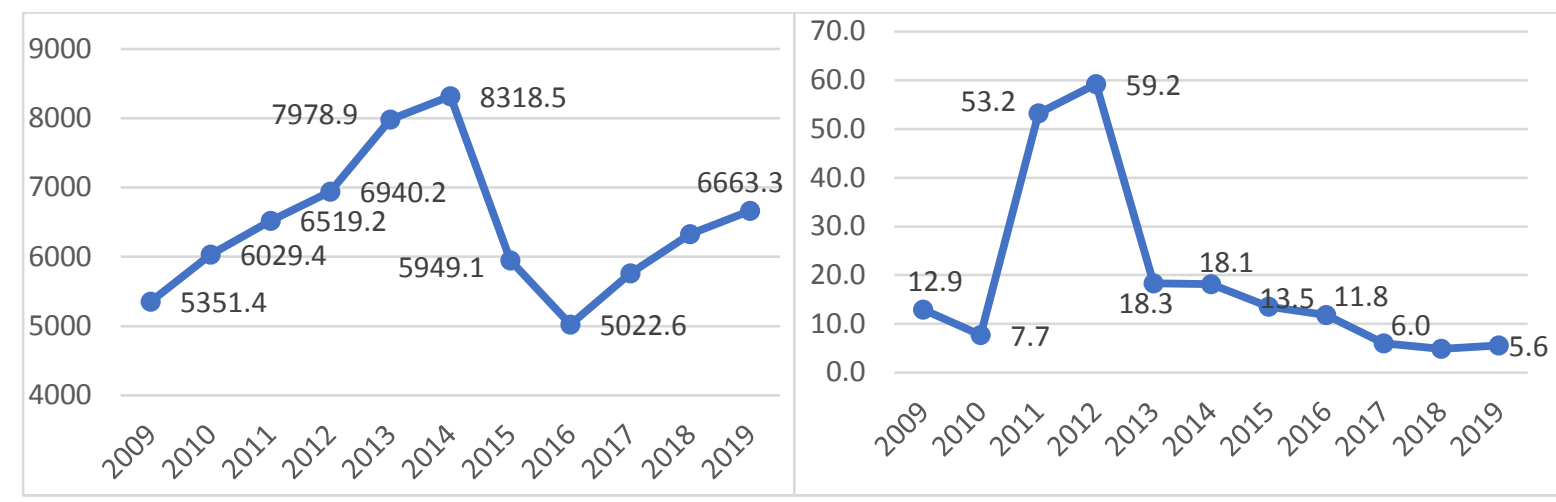

Source: World Bank 2020.

An important feature of Belarussian economy is its high share of public sector in employment and GDP (Figure 9). Despite a drop of almost 20 percentage points in the share of workers employed by the public sector in the last 20 years, close to 40 percent of the employed population still works in the public sector. This is a very large rate compared to other countries in Eastern Europe. For example, according to the World Bank, the share of employment in public sector in Czech Republic, Slovakia, Slovenia, Poland, Romania, and Serbia does not exceed 20 percent (World Bank 2014). Moreover, according to the National Statistical Committee of the Republic of Belarus, the public sector constitutes 69 percent of industrial production, 58 percent of investments, and 55 percent of GDP is formed by government consumption (National Statistical Committee of the Republic of Belarus n.d.).

There is enough scope for a larger private sector in Belarus, and such a structural change will have a significant effect on labor markets including the demand for skills and professional competences. The VET system in Belarus could anticipate this structural change and introduce the necessary reforms to ensure that its future graduates acquire the necessary skills and professional competences demanded by the growing private sector. 
Figure 9 Employed population of Belarus by sector of employment (\%)

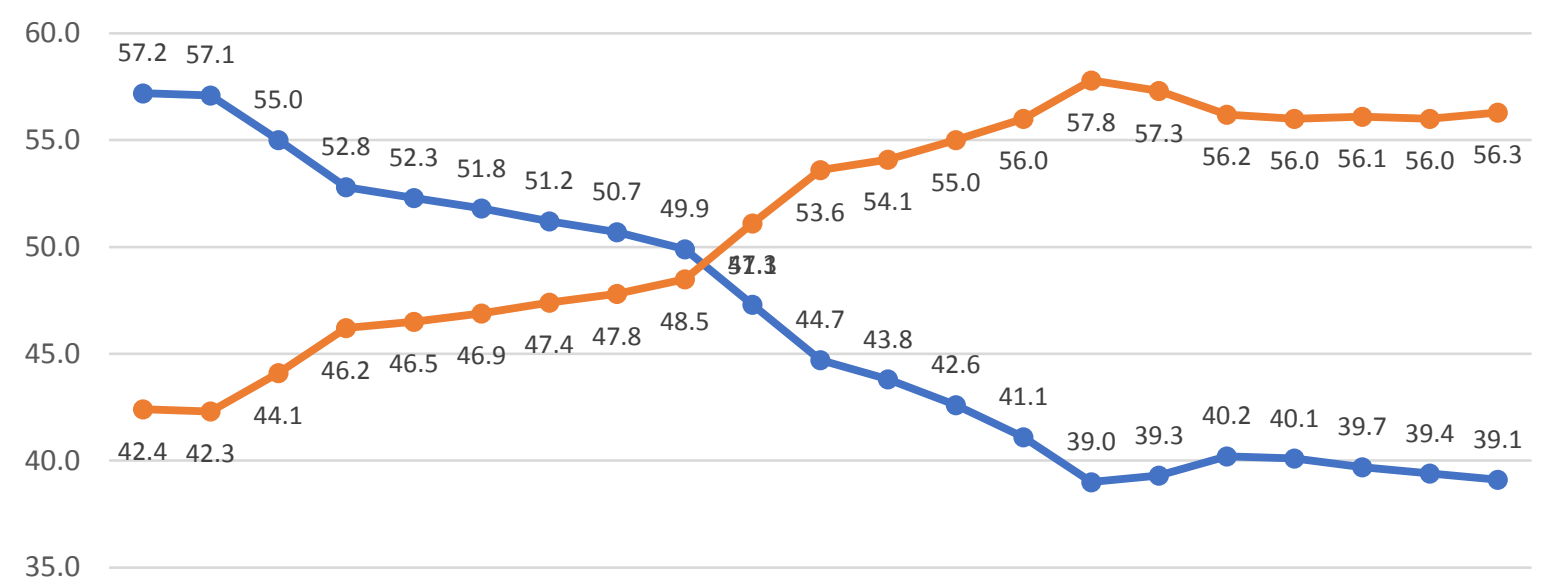

30.0

200020012002200320042005200620072008200920102011201220132014201520162017201820192020

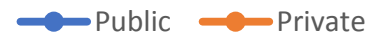

Source: National Statistical Committee of the Republic of Belarus 2020.

\section{METHOdOLOGY AND DATA}

One way of identifying the benefits of investing in education is to estimate the returns to schooling. The returns to schooling are defined as the increase in personal income associated with an increase in a one year of schooling, keeping all other things constant. This section describes the methodology and microdata (individual level) used to estimate the returns to schooling, distinguishing between VET students and students who graduated from other education tracks.

This section provides information on the students who are attracted to the VET system and examines whether they come from low socioeconomic backgrounds or in rural areas, among others. This information is important because it indicates the equity angle of public investment in education.

\subsection{Methodology}

The empirical analysis used in this report is based on a descriptive and regression analysis. The regression analysis of returns to education uses the standard methodology of Mincer wage equation and its estimation is based on ordinary least squares (OLS). This methodology is a standard that is often used by international organizations, universities, and research organizations worldwide to analyze the returns to investments in education, labor market outcomes of graduates, and the efficiency of education systems (Patrinos 2016).

The Mincer wage equation is a single-equation model that explains salaries of individuals as a function of education (measured in years of schooling or education attainments) and experience. It usually includes other variables, such as gender, region, year, industry of 
occupation and other controls to estimate a net effect of the investments in education on salaries. The Mincer equation provides estimates of the average monetary returns of one additional year of education, or alternatively, if the years of formal education are not available, of an extra level of education. This information is important for policy makers who must decide on education spending, prioritization of schooling levels, and a large set of education policy options (Patrinos 2016).

The Mincer regression model used in the analysis is the following:

$$
\begin{gathered}
\operatorname{Ln}(W)=\beta_{0}+\beta_{1} \cdot \text { Education }+\beta_{2} \cdot \text { age }+\beta_{3} \cdot \text { age } e^{2}+\beta_{4} \cdot \text { Gender }+\beta_{5} \cdot \text { Region }+\beta_{6} \\
\cdot \text { Year }+\varepsilon
\end{gathered}
$$

Where:

$\operatorname{Ln}\left(\boldsymbol{W}_{i}\right)$ is the logarithm of average monthly salary.

Education is a categorical variable for education attainment (higher education, SSE, VT, secondary education, basic education or below).

Age is an age of respondent (years).

Gender is a sex of individual (male=1).

Region is a region of Belarus (Brest, Vitebsk, Gomel, Grodno, Minsk, and Mogilev, as well as Minsk city).

Year is the year when the data were collected (2011-2019).

The coefficient $\beta_{1}$ gives the percent wage differential between two workers who differ by one year (by highest education level achieved) of schooling, holding other variables constant and is typically interpreted as the rate of return to schooling or rate of return to a given level of education compared to a reference group. Since the labor force survey of Belarus does not report information on the number of years of formal schooling, the main specification employs categorical variables for education, for example, education $=1$ if the individual has a higher education degree, education $=2$ if the individual's education attainment is SSE, education $=3$ if the individual's highest level of education is VT, education $=4$ if the individual's education attainment is general secondary, and education $=5$ if the individual's highest level of education is basic education. Our first choice for the base category was "basic education", but only 5 percent of the labor force had this education attainment. Therefore, we use general secondary education (11 years of schooling) as a reference group, the returns are estimated in relation to this reference group. We also estimated alternative specification of the Mincer equation in which SSE and VT are united in one single education category labelled VET education. Finally, the returns to education in the above specification are not net of costs, so therefore they should be interpreted as the private returns among individuals who did not have to pay for tuition fees-the majority of workers in Belarus. ${ }^{3}$

To test for heterogeneous returns to education by population subgroups, we also estimated the Mincerian wage equation for a subsample of young age cohort (individuals between the ages of 23 to 35), male / female, and different years. None of these alternative specifications changes the main results described below. The estimation of the returns to education is

\footnotetext{
${ }^{3}$ The Mincer equation results presented here should be interpreted with caution since the methodology has intrinsic limitations such as omitted variable biased and self-selection. In addition, the results of the Mincer equation are more relevant in well-functioning or complete markets where the wages are equal to the marginal productivity of labor.
} 
complemented by a description of the socioeconomic background and learning outcomes of students in VET compared to general education tracks.

\subsection{Data}

The methods described above are implemented using microdata taken from the National Statistical Committee of the Republic of Belarus from 2011-2019 and the Programme for International Student Assessment (PISA) from 2018.

The returns to schooling are estimated using data carried out by National Statistical Committee of the Republic of Belarus from 2011 to 2019. This data set contains information on levels of education, sociodemographic characteristics, and earnings of Belarussian workers. Its survey is representative of the population of Belarus. Descriptive statistics on main variables for the 2011-2019 period can be found in Table 4. The total sample size is 80,851 observations covering the period 2011 to 2019. The variable salary contains 34 percent of missing observations and variable education contains 3 percent of missing observations.

Table 4 Descriptive statistics of the sample by year

\begin{tabular}{|c|c|c|c|c|c|c|c|}
\hline Year & $\mathrm{N}$ & $\begin{array}{l}\mathrm{N} \text { (non- } \\
\text { missing } \\
\text { wages) }\end{array}$ & $\begin{array}{c}\text { Total } \\
\text { monthly } \\
\text { nominal } \\
\text { salaries }\end{array}$ & $\begin{array}{c}\text { Subsistence } \\
\text { level }\end{array}$ & $\begin{array}{c}\text { Total } \\
\text { monthly } \\
\text { real } \\
\text { salaries (in } \\
\text { prices of } \\
2020 \text { ) }\end{array}$ & Age & $\begin{array}{l}\text { Gender } \\
\text { (male) }\end{array}$ \\
\hline 2011 & 9840 & 5930 & 140 & 62.20 & 711.6 & 39.0 & 44.8 \\
\hline 2012 & 9500 & 5974 & 259 & 92.70 & 859.0 & 39.6 & 45,2 \\
\hline 2013 & 9008 & 5747 & 352 & 115.70 & 732.7 & 40.0 & 44.7 \\
\hline 2014 & 9055 & 5937 & 419 & 143.00 & 737.1 & 40.1 & 44.9 \\
\hline 2015 & 9067 & 6163 & 451 & 170.00 & 673.1 & 40,8 & 44.2 \\
\hline 2016 & 8715 & 5759 & 481 & 193,00 & 631.1 & 41,2 & 44.0 \\
\hline 2017 & 8229 & 5498 & 524 & 215.00 & 614.7 & 41.5 & 44.5 \\
\hline 2018 & 8693 & 6056 & 607 & 233.00 & 672.1 & 41.3 & 44.5 \\
\hline 2019 & 8744 & 6221 & 700 & 257.00 & 741.7 & 40.9 & 44.7 \\
\hline
\end{tabular}

Source: Authors' calculations based on data from the National Statistical Committee of Belarus 2011-2019.

The total monthly salary includes salary from the main job, subsidies from the main job, inkind wages from main job and wages (cash and in-kind) and subsidies from other jobs. The World Bank calculated real wages using the CPI indexes adjusted to express the units in prices of 2020, removing the sample individuals with salaries under subsistence level. ${ }^{4}$ Detailed descriptive statistics by year is presented in Table 4.

Although real average salaries in Belarus on the basis of the household survey are lower than real average salaries (National Statistical Committee of the Republic of Belarus 2011-

\footnotetext{
${ }^{4}$ The subsistence level is determined by decrees of the Government of Belarus on the quarterly basis. The World Bank calculated yearly average as a mean of quarterly subsistence levels. This follows the methodology of Chubrik and Shimanovich (2013).
} 
2019), the dynamics of salaries measured by two sources during the period of analysis are consistent (figure 8). Differences in real salaries between listed sources are caused by the process of data collection: official salaries estimations used by National Statistical Committee of the Republic of Belarus are based on the enterprise data, and household survey data are retrieved from population based on survey data. The dynamics of real salaries in Belarus shows the stagnation of real salaries: recovery of 2017-2019 has not yet compensated the decline of 2014-2016 and overall real salaries of 2019 are lower than in 2012. Furthermore, the distribution of the natural logarithm of wages shows that it is close to normal distribution enabling a robust estimation of the Mincerian equation (See annex, figure A1).

Figure 10 Dynamics of real salaries reported by National Statistical Committee of the Republic of Belarus and those obtained by microdata

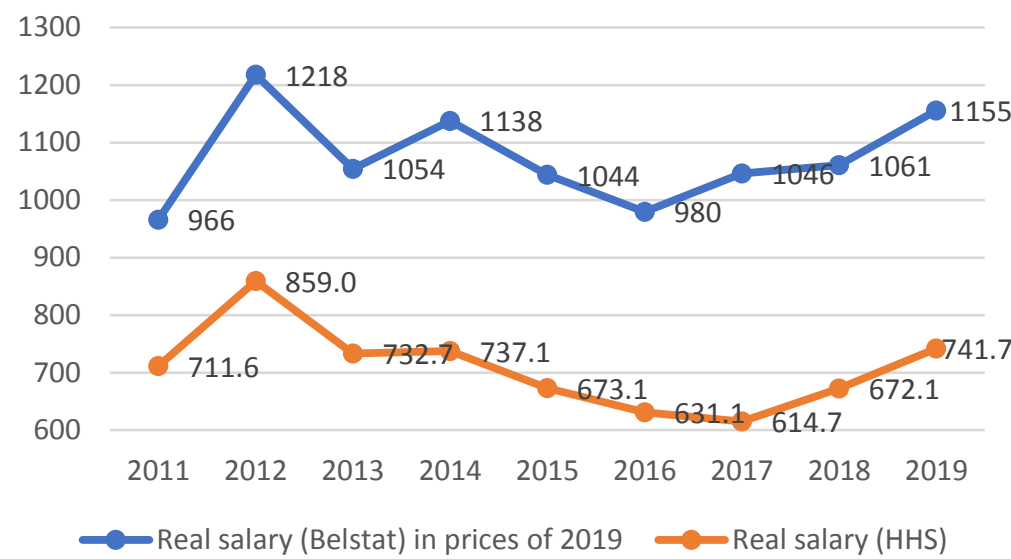

Source: Authors' calculations based on data from the National Statistical Committee of Belarus 2011-2019. Note: Salaries are calculated in denominated Belarussian roubles (BYN).

The analysis of socioeconomic status and learning outcomes of VET compared to other students is based on data from PISA 2018 (OECD 2018). PISA is an international survey which measures the ability of 15 -year-old students to use their reading, mathematics, and science knowledge and skills to meet real-life challenges. The survey is carried out for OECD member countries and partner countries, and it includes observations for 78 countries of the world. In 2018, Belarus participated in PISA assessment for the first time and the World Bank uses this dataset for the analysis of socioeconomic background and educational outcomes of VET students.

PISA complements its student assessment with a context questionnaire with information on the type of education track in which a student is enrolled as well as the socioeconomic characteristics of the student's family, including parental education, occupations, and household assets, among many other criteria.

\section{RESULTS}

\subsection{Labor market outcomes of VET graduates in Belarus}


Based on the Belarus household survey of living standards, the average salary of the population with higher education is $\mathbf{4 7}$ percent higher than the salaries of secondary education graduates. Unconditional wage premia for vocational education are considerably lower: only 9 percent for all VET graduates (including both SSE and VT graduates). Disaggregating the VET section, wage differentials are 11 percent for SSE and 6 percent for VT (Table 5). These wage premia have been relatively constant over the last 10 years.

Table 5 Real average total monthly salary by educational level, 2011-2019

\begin{tabular}{|l|c|c|c|c|}
\hline \multicolumn{1}{|c|}{ Level of education } & $\begin{array}{c}\text { Number of } \\
\text { observations }\end{array}$ & $\begin{array}{c}\text { Share of the } \\
\text { population (\%) }\end{array}$ & $\begin{array}{c}\text { Salary } \\
\text { (BYN) }\end{array}$ & Premia \\
\hline Higher education & 19,188 & 24.3 & 883 & $147.3 \%$ \\
\hline VET (including SSE and VT) & 39,717 & 50.4 & 657 & $109.6 \%$ \\
\hline SSE & 26,450 & 33.6 & 666 & $111.1 \%$ \\
\hline VT & 13,267 & 16.8 & 637 & $106.2 \%$ \\
\hline General secondary education & 15,780 & 20.0 & 600 & $\begin{array}{c}\text { Base }= \\
100.0 \%\end{array}$ \\
\hline Basic education and below & 4,162 & 5.3 & 544 & $90.7 \%$ \\
\hline
\end{tabular}

Source: Authors' calculations based on data from the National Statistical Committee of Belarus 2011-2019.

The results of the returns to education under four different specifications are shown in Table 6. Columns 2 and 3 in Table 6 show the returns to the VET sector as a whole, while columns 4 and 5 disaggregates the VET sector into SSE and VT. In these two specifications, the reference education category is general secondary education, so all the coefficients related to the different education levels in Table 6 should be interpreted as returns or labor market premia with respect to having a general secondary diploma. All regressions include regional and year fixed effects and the full set of results are available (see annex, table A1).

The results indicate that higher education graduates earn 37 percent higher wages compared to the wages of workers with a general secondary degree. VET education yields a wage premium as well but significantly lower, 10 percent for the VET sector as a whole, 13 percent for SSE and 5 percent for VT. With the exception of VT, these returns are significantly lower among young workers (between the ages of 23 and 35), probably due to limited work experience.

Notice that the difference in returns to education between the full sample and young workers is substantial among university graduates but relatively mild for VET graduates (and zero for VT graduates), suggesting that the salaries of vocational graduates will remain almost flat during their professional life cycle. The returns to experience, proxied by age, are positive, as expected, and with a decreasing slope (captured by the negative coefficient on "agesquared"). Results also show that male workers enjoy a considerable wage premium of 25 percent over the wages of women with the same level of education, experience, and located in the same region of Belarus. Not surprisingly, wage premiums in capital city (Minsk) and the Minsk region are positive and significant (results from annex, table A1). 
Table 6 Returns to education in Belarus

\begin{tabular}{|c|c|c|c|c|}
\hline & Full Sample & $\begin{array}{c}\text { Youth (23- } \\
35)\end{array}$ & Full Sample & Youth (23-35) \\
\hline $\begin{array}{l}\text { Higher } \\
\text { education }\end{array}$ & $0.370 * * *$ & $0.293 * * *$ & $0.371 * * *$ & $0.293 * * *$ \\
\hline VET & $0.101 * * *$ & $0.0747 * * *$ & & \\
\hline SSE & & & $0.128 * * *$ & $0.0877^{* * *}$ \\
\hline VT & & & $0.0450 * * *$ & $0.0461 * * *$ \\
\hline Basic education & $-0.0990 * * *$ & $-0.101 * * *$ & $-0.0998 * * *$ & $-0.102 * * *$ \\
\hline Age & $0.0484 * * *$ & $0.0889 * * *$ & $0.0485^{* * *}$ & $0.0892 * * *$ \\
\hline Age-squared & $-0.0006 * * *$ & $-0.0012^{* * *}$ & $-0.00059 * * *$ & $-0.0012 * * *$ \\
\hline Sex (male) & $0.256 * * *$ & $0.355^{* * *}$ & $0.262 * * *$ & $0.356 * * *$ \\
\hline Observations & 52,534 & 12,192 & 52,534 & 12,192 \\
\hline R-squared & 0.266 & 0.281 & 0.270 & 0.282 \\
\hline
\end{tabular}

Source: Authors' calculations based on data from the National Statistical Committee of Belarus 2011-2019. Note: The reference education category is general secondary. All regressions include regional and year fixed effects. Full results in annex, table $A 1 * * * p<0.01,{ }^{* *} p<0.05,{ }^{*} p<0.1$.

The results presented in Table 6 assume that the age-wage profiles are homogeneous across workers with different education levels. We relax this assumption by estimating separate wage equations for workers in each of the different education levels. These allows us to get separate age-wage profiles, controlling for all the variables included in the Mincer specification, for workers with different levels of education. The results are presented in Figure 11. These profiles show that higher education graduates enjoy a relatively steep increase in their wages, starting early in their careers and up to age 45, after which point, their wages begin decreasing. The age-wage profiles are significantly flatter for VET graduates, both SSE and VT, compared with the profiles of university graduates. For VET graduates, wages plateau earlier in their life cycle so the decline starts earlier, and they end up with wages that could even be lower than at the beginning of their careers. Perhaps even more relevant is the difference between lifelong earnings of graduates of VT and general secondary education; the difference is basically zero, corroborating the low returns to VET as a whole and VT in particular. 
Figure 11 Conditional age-wage profile

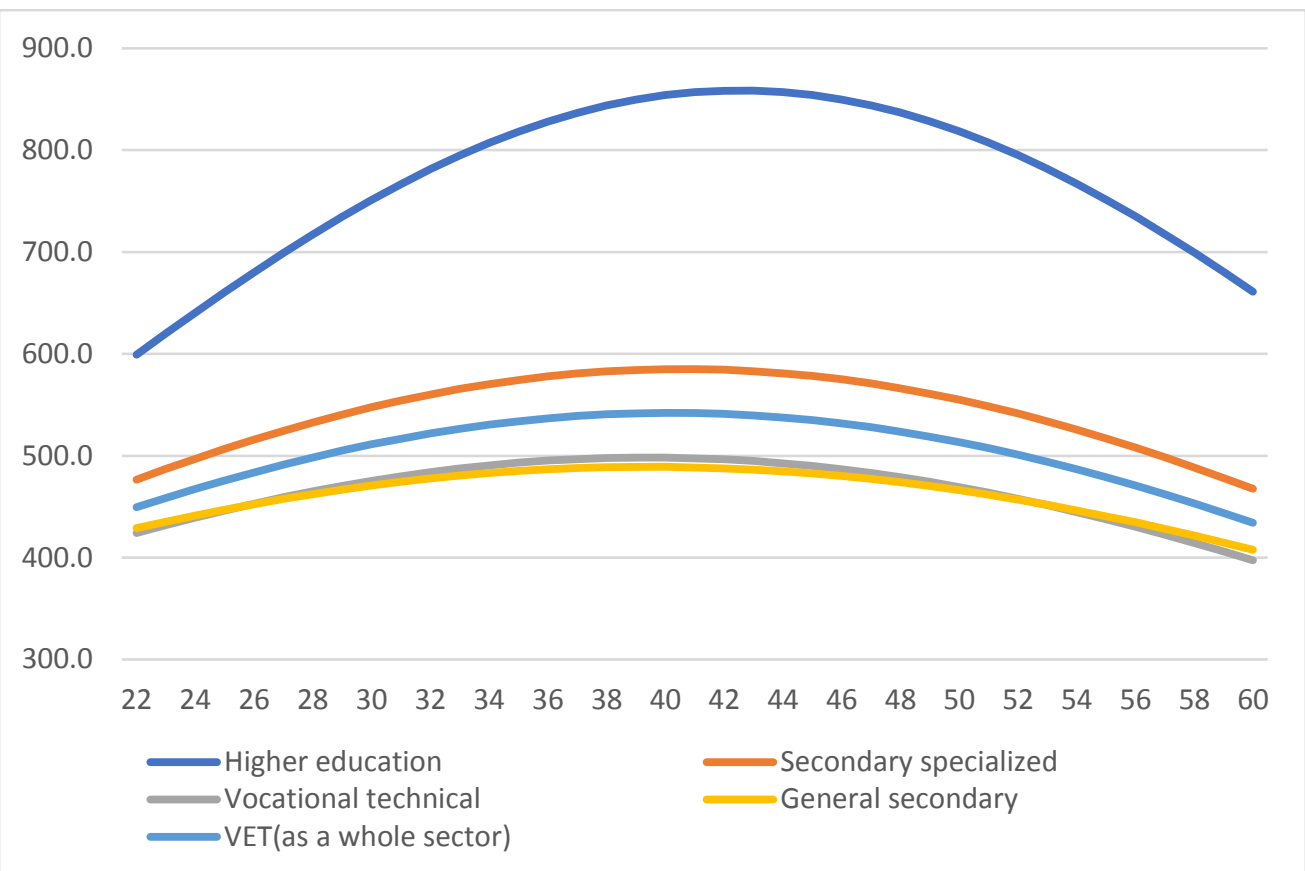

Source: Authors' calculations based on the estimation presented in Table 6.

The results so far assume that the returns to schooling are constant over time, and this assumption is based on estimations that separate Mincer equations for each year covered by data (2011-2020). We estimate the year-specific returns using the entire sample and separating the effects for the population ages 23 to 35 years old. The results are summarized in

Figure 12 and the detailed results are included in table $A 2$ in the annex.

The results show that the returns for a university diploma increased from $\mathbf{4 2}$ percent in 2011 to $\mathbf{5 2}$ percent on $\mathbf{2 0 2 0}$ and the same patterns, although at a lower level, is true for younger workers. In contrast, return to SSE and VT, compared to general secondary, remained stable throughout this period and among young workers it even shows a long-term negative trend. During the crisis years of 2014-2016 when overall wages were declining significantly, the returns for higher education and SEE increased (less so for the latter). However, returns to VT stayed constant during the crisis, and it was even negative among young workers in 2014 and remained statistically insignificant ever since. These patterns of the returns to education, particularly the returns to VT among young workers suggest that recent graduates from VT do not enjoy a labor market advantage over workers with a general secondary education diploma and they could be even more vulnerable to negative macroeconomic shocks. ${ }^{5}$

Figure 12 Evolution of the returns to education in Belarus, full sample (left), young population (right)

\footnotetext{
${ }^{5}$ For completeness, we also estimate separate Mincer equations by geographical region and the results are presented in Table A3 in the annex. The results show that the returns to VET are very low - not significantly different from general secondary-in Brest and Minsk City.
} 

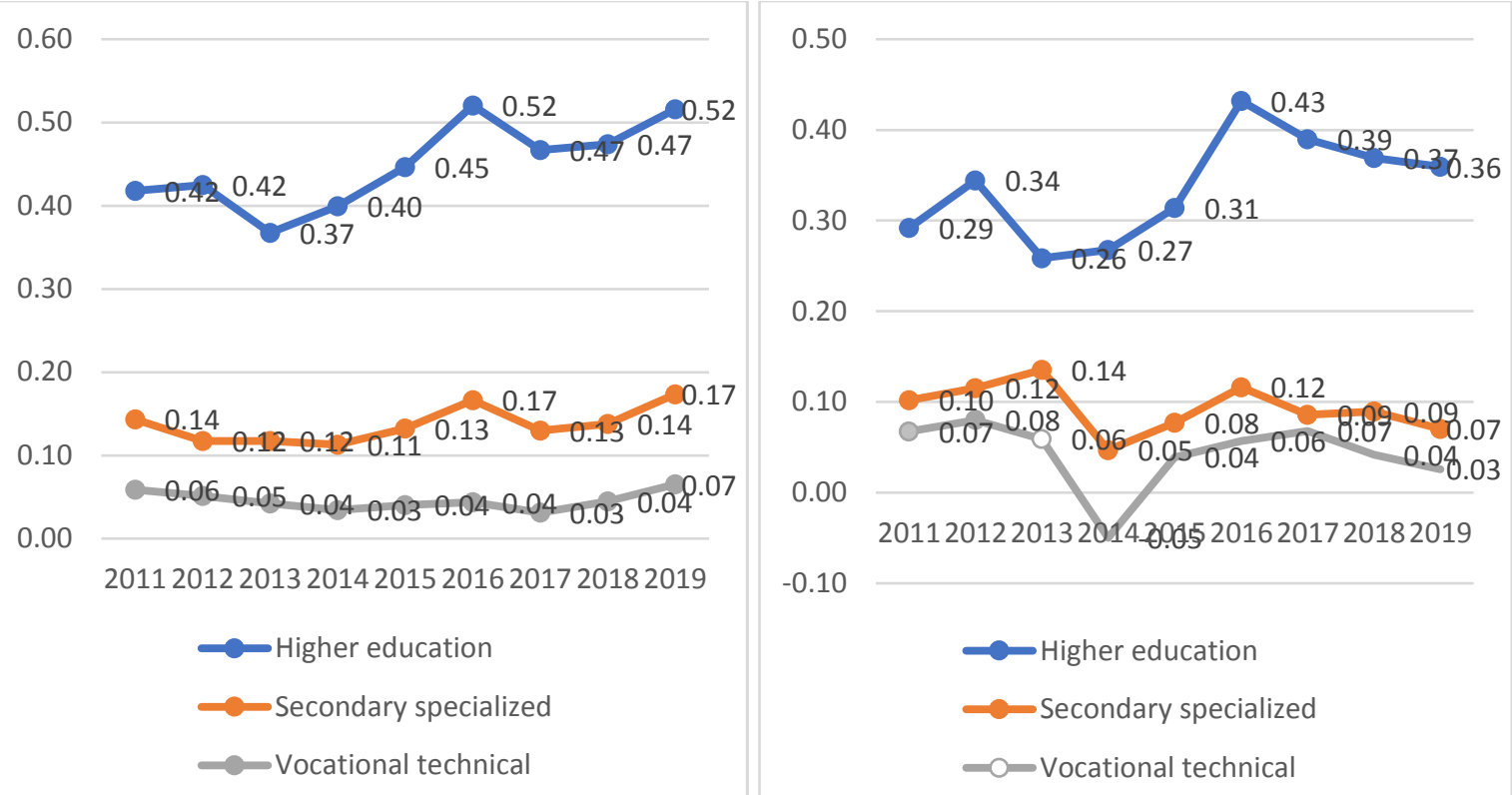

Source: Authors' calculations based on data from the National Statistical Committee of Belarus 2011-2019. Note: The coefficient for VT among the young population are statistically insignificant for the period 2013 to 2019.

\subsection{Learning outcomes and socioeconomic background of VET students}

This section exploits the PISA 2018 data set to quantify the differences in learning outcomes and socioeconomic background between VET and general education students. Moreover, for the purposes of this report, the analysis is restricted to students who finished lower secondary education (grade 9) and are already enrolled in grade 10, either in a VET institution or a general secondary school. The data set includes 3,290 students, 74 percent of which are part of the general education track and 26 percent are enrolled in a vocational education track-most of whom are male students (Table 7).

Table 7 PISA sample distribution by ISCED orientation and gender (\%)

\begin{tabular}{|l|c|c|c|c|}
\hline ISCED orientation & $\begin{array}{c}\text { Number of } \\
\text { observations }\end{array}$ & Share (\%) & Male \% & Female \% \\
\hline General & 2,429 & 73.8 & 43.8 & 56.2 \\
\hline Vocational & 861 & 26.2 & 69.2 & 30.8 \\
\hline Total sample & 3,290 & 100.0 & 52.2 & 47.8 \\
\hline
\end{tabular}

Source: Authors' calculations based on data from PISA 2018.

Figure 13 shows VET and general education students' parental education achievement. VET students have parents with significantly lower education attainment, for instance, only 14 percent of fathers of VET students have a university degree, compared to 32 percent among students from the general education track. A large share of students in the VET track have parents with a VET diploma, either SSE or VT. In contrast, students in the general education track are less likely to have a parent with a vocational degree, especially a VT degree. 
Figure 13 Parental education level of VET and general education students (mothers on the left and fathers on the right)

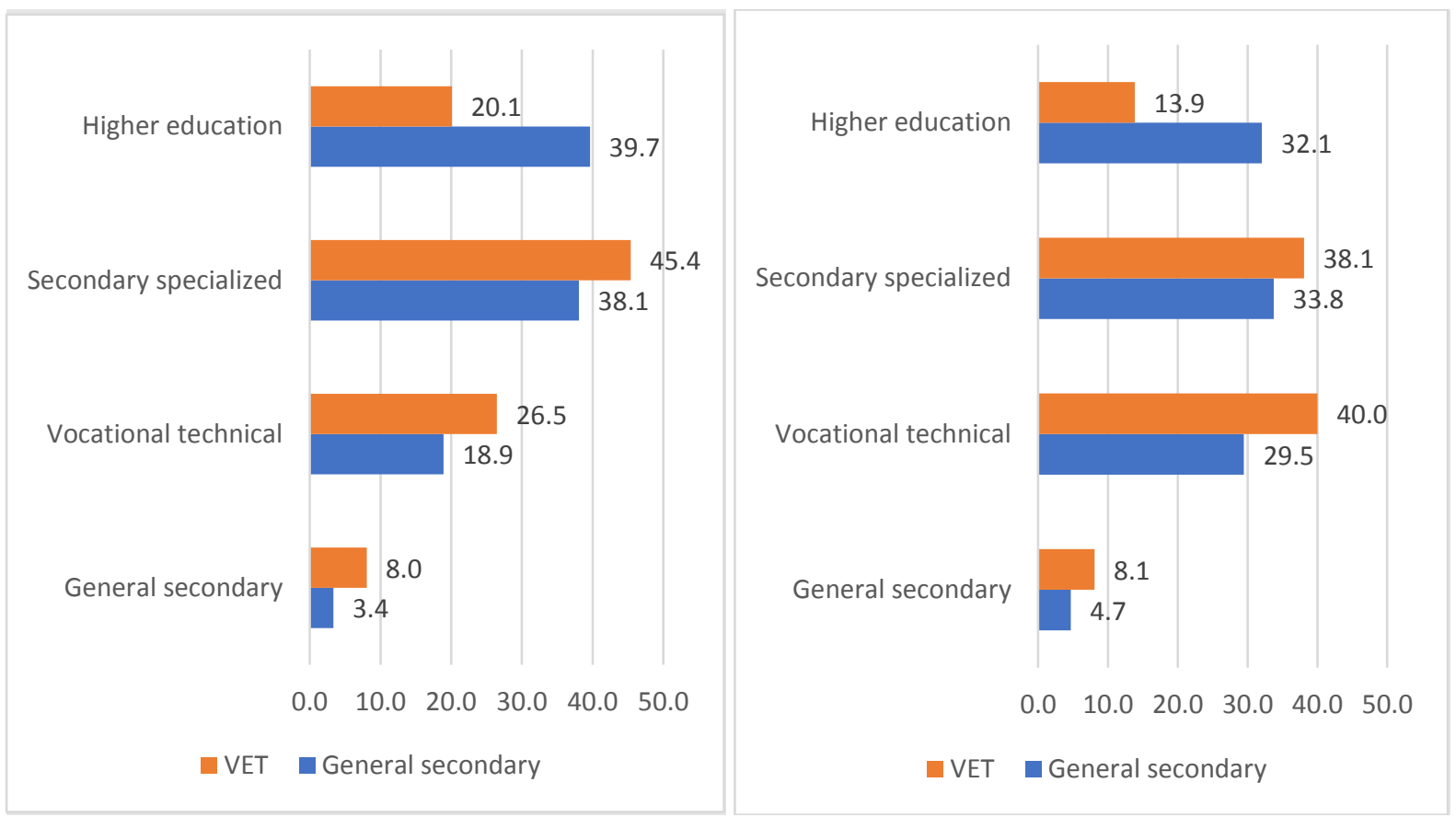

Source: Authors' calculations based on data from PISA 2018.

Given the differences in parental education attainment between VET and general education students, it is not surprising that VET students tend to have a more disadvantaged background. As shown in Figure 14, the share of VET students in the lowest (poorest) quintile of the income distributed, as reported by the PISA context questionnaire, is twice as high compared to the share of general education students. In contrast, the share of VET students in the highest quintile or the richest 20 percent of the population, is almost four times lower than the share of general education students in this income group.

Figure 14 Share of VET and general education students by income quartile

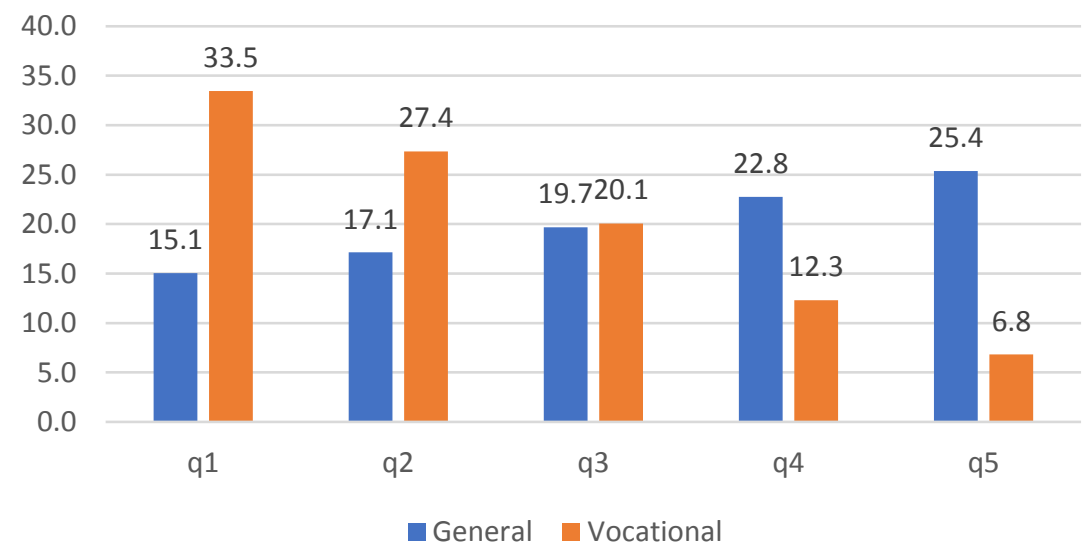

Source: Authors' calculations based on data from PISA 2018.

The PISA survey measuring socioeconomic status (SES) indicates that the VET track included an adverse selection of disadvantaged students, which affected completion rates. For instance, 76 percent of students in the general track responded that they expected to 
complete university degree compared to only 48 percent of students in the VET track. While this suggests a negative perception among VET students, the Belarus education system provides other pathways into higher education.

The differences in SES are reflected in differences in test scores between VET and general education students. VET students have significantly lower PISA scores in mathematics, reading and science compared to students in the general track. As depicted in Figure 14, the average difference between general education and VET students is between 56 points for science and 70 points for reading. These differences in test scores are substantial, equivalent to more than one year of formal schooling. All the information presented in this section corroborates that the VET track tends to receive more disadvantaged students compared with the general track which is true not only for Belarus but for most countries in which vocational education is part of the formal upper secondary education system.

Figure 15 Differences in PISA results between VET and general education students

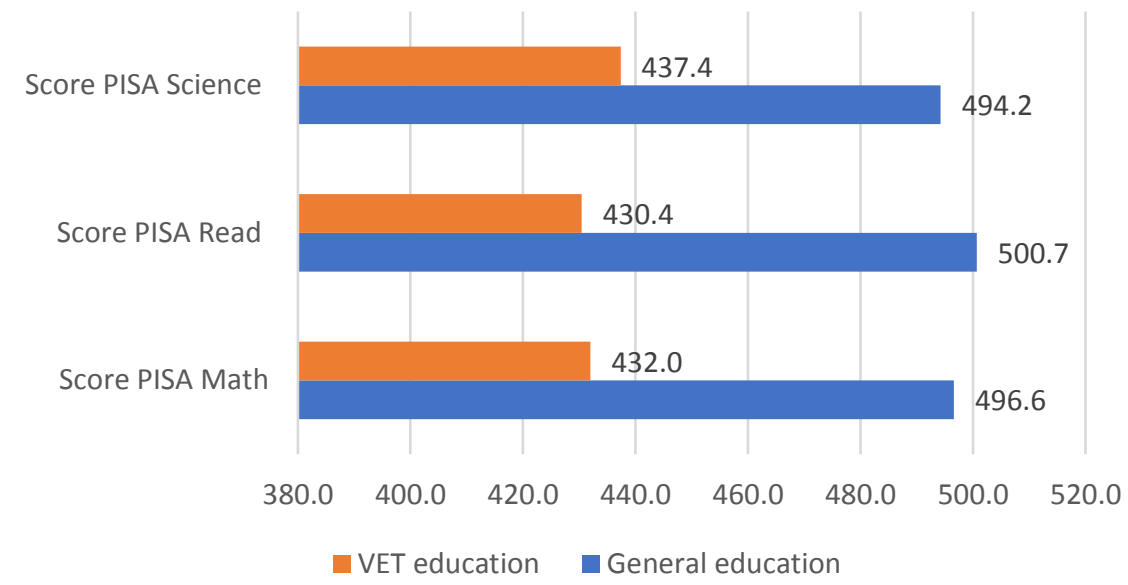

Source: Authors' calculations based on data from PISA 2018.

\subsection{Gender differences}

Women in Belarus are on average better educated than men (Figure 15). The share of women with a university or an SSE degree in the workforce is higher than the share for men with these education attainments. Men are more likely than women to have a VT or just a general secondary education degree. These gender imbalances in favor of women are not exclusive of Belarus; the situation is similar in Russia and other post-Soviet countries, where women are more likely to be involved in higher education while men pursue a VET education.

However, despite having a larger education endowment, as it is shown in Table 6, women earn 25 percent lower wages than men with the same education level, age (as a proxy for experience) and in the same geographical region. This is a large gender imbalance especially considering that women perform significantly better in numeracy and literacy (as measured by PISA), which, in the absence of gender discrimination, should manifest as a positive wage premium compared with men with similar characteristics and geographical location. 
Figure 16 Gender distribution by level of education

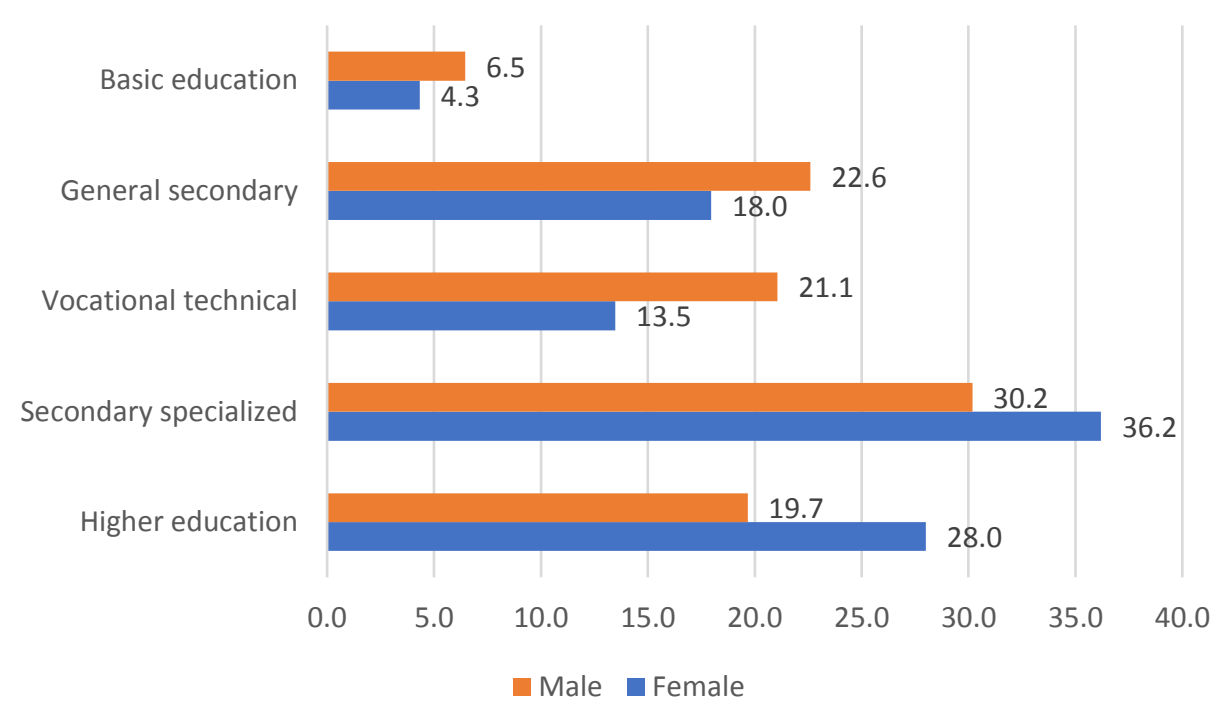

Source: Authors' calculations based on data from the National Statistical Committee of Belarus 2011-2019.

The lower wages associated with women may be accounted for by older cohorts (see Table 6). It is a relatively recent fact that women have entered the labor market with higher education attainments. However, estimations of the returns to education among workers ages 23 to 35 show that young women earn 35 percent less than men with the same education level, experience and in the same geographic location (see Table 6 and table A1 in the annex). This is puzzling and suggests a labor market discrimination against women that cannot be accounted for by characteristics that are related to productivity and market value.

\subsection{Interpretation of labor market outcomes of VET education}

Overall, the results indicate that the labor market outcomes of the VET system are only marginally positive even though costs are not included in the analysis. Graduates of SSE have a 13 percent wage premium compared with workers with a secondary education diploma, while graduates from VT show more modest returns and a decline in wages over time. Since 2009, the share of population with a VT degree fell, especially among younger workers in which the share passed from 22 percent to 10 percent in 10 years. The return to VT is less than 5 percent and among young workers, statistically speaking, VT no longer provides a positive wage premium over a secondary education diploma. Perhaps more concerning, VT graduates are more vulnerable to macroeconomic shocks, showing sharper declines in wages in relation to secondary education graduates, making the returns to VT negative during times of economic contraction.

The patterns of returns to education are consistent with previous studies for Belarus (Pastore and Verashchagina 2006; Chubrik 2013) and in recent estimates for Russia (Melianova and others 2020). The results from the Russian education system are particularly relevant given the institutional similarities between Russia and Belarus. The Russian labor market is also characterized by a high premium for higher education and low and decreasing premium for VET education (Figure 17). Additionally, the age-wage profile for Russian VET 
graduates shows the same pattern as in Belarus with mild increases in wages throughout the life cycle.

The low returns to VET, particular VT education in Belarus, could be related to the following factors: (a) adverse selection of students from poor socioeconomic background to VET; (b) low levels of basic cognitive skills, numeracy and literacy among VET students; (c) use of outdated equipment and an antiquated curriculum in VT education; and (d) a weak relationship between the VT system and the demands from employers, especially the private sector, resulting in a supply of skills in the VET sector that does not match the labor market demand.

Figure 17 Earnings ratio in Russian Federation by educational level
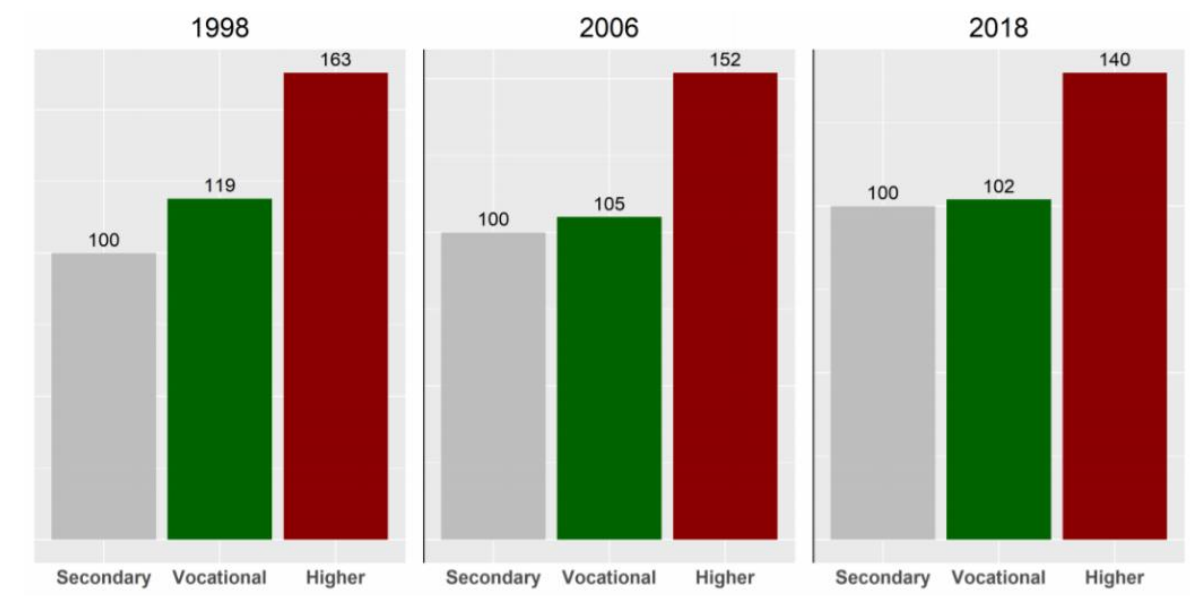

Source: Melianova and others 2020.

The selection of disadvantaged students into the VET sector leads to negative peer effects and poor examples of socialization, which exacerbates labor market outcomes of VET graduates and feeds the negative stigma around VET schools. This stigma further reduces the demand for VET, attracting more disadvantaged and struggling students. This cycle together with the fact that the VET sector is mainly public, does not create internal demand for updating and modernizing the curriculum and equipment. Consequently, vocational technical school students may face negative peer effects, outdated equipment, and a rigid curriculum. As a result, VET students are not getting the skills that are relevant for the labor market, including basic numeracy, literacy, and socioemotional skills. Without the right set of skills, VET graduates cannot secure a highly paid and stable job. These results show the need to undertake a major reform to the VET system, with an emphasis of VT schools to become an attractive option for younger generations within Belarus.

\section{POLICY Options}

This section draws on international best practices and offers policy options aimed at improving the relevance and quality of the VET systems and promoting more equitable learning outcomes. The selected policy areas are considered relevant for the Belarus VET system given the challenges it faces in terms of labor market outcomes of its VET graduates. 
While some of these policy options are not directly derived from the analysis performed in this report, they are closely aligned to international best practices aimed at increasing the effectiveness of a VET system and improving returns to VET. Further analysis of the specific constraints and challenges in each policy area in the Belarus VET sector would be needed to develop specific recommendations and a roadmap for implementation of such policies. The 5 policy options are as follows:

1. Upgrade VET facilities and equipment. Most up-to-date VET facilities and equipment will deliver better market-relevant training in support of the country's strategic economic priorities.

2. Strengthen employer engagement. The Belarusian VET system will be able to better meet labor market needs if employers and industry associations receive a formal role in defining strategic education priorities and have an incentive to participate.

3. Advance teacher professional development. The quality and relevance of VET teaching will be improved if VET institutions adapt formal performance appraisal and professional development processes for teachers and staff.

4. Collect and use data on labor market outcomes. The Belarusian VET system will be able to better prepare students to the world of work if it improves its capacity to make informed decisions by collecting and using data on labor market outcomes.

5. Improve foundational skills of VET students. VET students will have more equitable learning outcomes that will better prepare them for the future of work if VET programs focus on improving the foundational skills of VET students.

Upgrade VET facilities and equipment. The government of Belarus has identified the advanced technologies sector as a key strategic priority sector, which includes industries such as information technology, biotechnologies and nanotechnologies, robotics, and sustainable technologies. In support of the country's economic development objectives, VET institutions need to upgrade existing technical programs and establish new programs. This requires significant investment in modernizing institutional facilities, laboratory equipment, technological infrastructure, as well as updated curricula. Currently, outdated equipment and old facilities pose a significant challenge to the quality and relevance of VET programs. Moreover, facilities are not adequately equipped to support training inclusive of students and faculty with disabilities, and many institutional facilities do not meet environmental standards.

Most up-to-date VET facilities and equipment will deliver better market-relevant training in support of the country's strategic economic priorities. To support its investment in innovation-based development of industries, the government must upgrade VET equipment, laboratories, and facilities. International standards that are used at the World Skills competition can be used as an initial benchmark to assess the relevance of the current inventory of equipment. In the long-term, the Belarusian government should identify sustainable funding mechanisms that allow continuous upgrading of the teaching environment. VET systems in other countries utilize cost-sharing agreements with the industry to limit their dependence on public funding. VET institutions in Belarus can leverage existing partnerships with employers to receive in-kind resources, such as technical equipment or their employees' time to serve as VET teachers. In addition, work-based 
learning is an effective cost-sharing solution in a context of limited public funding because it (a) creates learning opportunities that VET schools with limited resources would not be able to provide, (b) eliminates the need to purchase expensive equipment, and (c) alleviates financial limitations by sharing training cost with the industry.

Strengthen employer engagement. In countries where industry determines the content of vocational programs, including qualification standards and assessments, VET better responds to industry needs and VET qualifications have currency in the labor market (Constant, Culbertson, Stasz, and Vernez 2014). A close cooperation with employers, trade unions, and trade associations is of critical importance to ensure that learning outcomes correspond with workplace demands. Institutional mechanisms help establish a consistent and systematic industry engagement in VET. Many countries have established formal industry bodies, typically in the form of industry skills councils, that are tasked with the provision of labor market intelligence, the development of occupational competency standards and qualifications as a foundation for training programs, as well as shaping the overall VET strategy. The government of Belarus has progressed substantially in the area of employer engagement in the recent years, following examples of international best practices. Since 2017, 13 sector skills councils were established that consist of sectoral line ministries, employers, and social partner organizations and are tasked with developing occupational standards (European Training Foundation 2020a). In 2019, a National Council on Qualifications Development was established, bringing together ministerial and social partner representatives to aid in the development of a National Qualifications Framework. On the local level, individual VET institutions engage in various forms of partnerships with employers, through the base enterprise agreements, governance arrangements, and other mechanisms. Despite these efforts, Belarus reported its biggest labor shortages in history in 2019, with students having a mismatch or gaps in qualitative skills needed in the labor market (European Training Foundation 2020b) - demonstrating the need for more and better industry engagement in VET delivery.

The Belarusian VET system will be able to better meet labor market needs if employers and industry associations receive a formal role in defining strategic education priorities and have an incentive to participate. While formal mechanisms for the engagement of employers in VET exist, there is significant room for improvement to render them more effective. Further analysis is necessary to evaluate the full scope and effectiveness of existing mechanisms to engage employers at different levels of the VET provision (e.g. sector skills councils) in order to identify areas for improvement. One such potential area for improvement could be establishing regionally specialized sector skills councils that can better reflect the needs of the specific regional labor market. The government of Kazakhstan introduced advisory councils on different levels of the economy (national, regional, and sectoral) to encourage employers' active participation in the establishment of labor market relevant practices on all levels of the VET provision (Álvarez-Galván 2014). However, providing formal mechanisms for industry engagement is not sufficient by itself, as employers often choose not to participate in existing engagement pathways: over 45 percent of vocational technical schools in Belarus lack representation from employers in their school board (European Training Foundation 2021). Creating incentives that encourage employer participation in existing pathways for engagement with the ministry and VET institutions is therefore essential. Moreover, it is important to ensure that engagement mechanisms exist for different levels of VET provision 
and provide an accurate representation of the industry, including private and public employers as well as SMEs. The World Bank is currently conducting a Training Assessment Project in Belarus that will shed light on key issues with employer engagement.

Advance teacher professional development. The quality of VET instruction depends on the qualifications and competencies of teachers and trainers. Qualified teachers need to possess pedagogical skills, theoretical knowledge, practical competencies, as well as up-to-date industry experience to effectively deliver relevant content. As labor market needs evolve and new technologies facilitate teaching, VET teachers need incentives to develop accordingly. In Belarus, over 60 percent of VET principals identify a lack of qualified or well-performing VET teachers as a roadblock to high quality teaching in their school (European Training Foundation 2021). While there are continuous professional development plans for VET teachers in Belarus, the extent to which they are effectively implemented is difficult to evaluate, as the monitoring of action plans has not been published (European Training Foundation 2021). While VET teachers in Belarus are required to undergo pedagogical training and recertification every 5 years, the compulsory minimum hours for pedagogical training are very low: teachers need to only spend 72 hours over 5 years (European Training Foundation 2021). There is currently no explicit focus on socioemotional skills in the pedagogical training of VET teachers. In addition, there are no formal requirement for VET teachers to update their industry knowledge or technical competence. Schools and industry sometimes cooperate to contribute to teacher continuous professional development through interventions like industry placements, however, less than 20 percent of teachers participate in these workbased development activities (European Training Foundation 2021).

The quality and relevance of VET teaching will be improved if VET institutions adapt formal performance appraisal and professional development processes for teachers and staff. As a first step, it is necessary to evaluate existing continuous development plans for VET teachers to understand their scope and effectiveness. A functioning formal appraisal process that includes the evaluation of performance and recommends professional development interventions to close potential gaps could significantly improve quality and relevance of teaching. The government of Belarus should consider possible ways to incentivize the professional development of VET teachers. Tying monetary incentives to performance outcomes or linking performance requirements to promotions (for example, into the managerial track) could improve VET teaching. Moreover, continuous professional development requirements within the re-certification process for VET teachers needs to be expanded to include technical industry knowledge and pedagogical training for teaching socioemotional skills. Including formal provisions for updating industry knowledge and experience is particularly critical in light of the government's economic development objectives. International examples show that partnering with local industry to reskill and upskill VET teachers' technical skills has been key to foster continuous professional development (OECD 2010). VET institutions in Belarus can leverage their existing relationships with employers to foster professional development of VET teachers, which can include employer-led industry training of teachers or opportunities for workers to teach part-time in VET institutions. Three to four week-long part-time internships for teachers and trainers have provided an effective alternative to traditional professional development (Fazekas and Field 2013; Cort, Härkönen and Volmari 2004). In China, work placement periods for VET instructors are an integral part of their professional development. The National Council requires 
instructors in vocational institutions to spend either one month per year or two months in two years in the industry. These work placements can serve to update technical skills, strengthen contacts with employers, plan work-based learning activities for VET students, or train in-company trainers on how to teach students. Alternatively, some countries, such as Switzerland, have enabled mid-career industry practitioners to teach part-time while continuing to work in the industry to increase relevance of VET teaching (OECD 2010, 2014). In Shanghai, a third of vocational instructors are working part-time while teaching (Kuczera and Field 2010). Teachers who have worked in the industry have access to a strong network of contacts and personal relationships with colleagues that can further strengthen the relationship between VET institutions and the industry (Kis 2017).

Collect and use data on labor market outcomes. A government's objective in VET budget allocations should be to fund labor market outcomes and not the supply of training, meaning that students are not trained for the sake of holding a degree but rather to successfully enter the labor market and earn higher wages. Systematically collecting data through a formal information management system allows training institutions and policy makers to evaluate relevance of training programs, decide on the discontinuation of ineffective programs, and prioritize effective programs or institutions in budget allocations. Institutions that demonstrate market relevance of programs by proven labor market outcomes (for example, a strong graduate-employment rate) should be awarded greater funding opportunities that allow them to expand those successful programs. Reliable and complete data on labor market outcomes and returns for graduates of specific programs can further help students and parents make informed occupational choices. Data on labor market returns can also provide evidence to discredit prejudices or biases against certain occupations and increase their attractiveness. A recent World Bank study analyzing female enrollment in male-dominated vocational programs in Ethiopia found that the perceived future prospects in a profession was one of the most important motivating factors contributing to occupational choices (Buehren and Salisbury 2017). Many VET institutions in Belarus are not collecting data on training outcomes, including employment, job placement rates, graduates' earnings, and employer satisfaction - because there is no formal requirement to enforce such data collection. Moreover, there is no formal career guidance to effectively support decisions made around occupational choices. While the government of Belarus approved a concept for professional career guidance in 2014 , there is significant room for improvement to provide personalized career guidance to students that includes accurate labor market information. In addition, teachers are often expected to assume the role of career guidance counselors without any formal training or access to relevant labor market information.

The Belarusian VET system will be able to better prepare students to the world of work if it improves its capacity to make informed decisions by collecting and using data on labor market outcomes. The government of Belarus is currently establishing a comprehensive education management information system (through the Bank-funded Education Modernization Project) that can serve as a foundation for VET institutions. Further analysis is necessary to determine how that system can be utilized to meet the needs of the VET institutions. Additionally, the Bank-funded Higher Education Modernization Project in Belarus is piloting graduate tracer studies that could serve as a basis for collecting data on training outcomes of VET graduates. This data can then be utilized to improve career guidance counseling. Likewise, the government should consider further investment in career guidance 
solutions in secondary school as well as throughout VET education. Possible solutions could include appointing professional career guidance counselors, one-stop-shop career guidance centers as is the case in Finland and Germany, or a mobile phone application that would guide students through different career paths like developed in Australia. Helping students understand the labor market returns and educational requirements for different professions through career guidance counseling can increase demand for VET programs. Clarifying specific requirements that allow students to move between VET and general or higher education could further facilitate informed decisions and occupational mobility.

Improve foundational skills of VET students. Work is becoming increasingly intensive in nonroutine cognitive tasks and labor market demand is shifting toward higher order cognitive skills and socioemotional competencies (World Bank 2019). As labor market needs are changing, workers have to be prepared to evolve accordingly. Foundational cognitive skills build a critical base for lifelong learning and support long-term occupational mobility (OECD 2014). It is therefore not surprising that foundational skills, such as literacy, numeracy, and socioemotional competencies, are valued by employers and yield higher labor market returns. Our data show that VET students in Belarus have significantly lower foundational skills than their peers in the general academic track. The adverse selection process of relatively socioeconomically disadvantaged students may be a contributing factor to VET students having lower foundational skills than their peers in the general academic track. This perpetuates a cycle of inequality, wherein those students tend to experience lower returns on the labor market because they have lower levels of foundational skills. While it is theoretically possible for all VET graduates to pursue higher education, there is no data available on how many VET students actually enter and complete university education at some point in their academic pathway. Experience in other countries indicates that the transition from VET to higher education is often more difficult in practice than its theoretical design for permeability between these two academic tracks. Weak foundational skills could make it practically impossible to successfully pursue higher education after completing a VET degree.

VET students will have more equitable learning outcomes that will better prepare them for the future of work if VET programs focus on improving the foundational skills of VET students. VET programs in Belarus need to place greater importance on the development of stronger foundational skills and socioemotional competencies by revising curricula and investing assessment and remedial education to close existing gaps at the onset of VET. Socioemotional skills, in particular, should be integrated into qualifications, competency standards, and assessments of VET programs as much as possible (Brewer and Comyn 2015). While even the most advanced economies struggle to incorporate socioemotional skills in qualification standards and assessments, some countries have successfully managed to include them in curricula. In Singapore's Institutes for Technical Education (ITE), 15 percent of the curriculum is devoted to socioemotional skills. Strong foundational skills would further enable VET students to transition into the academic track more easily. This requires upgrading competencies of VET teachers to effectively deliver socioemotional skills training and utilize technology to facilitate new pedagogical approaches (see policy option 3 ). 


\section{FINAL REMARKS}

This report shows the need to introduce reforms to improve the effectiveness of the VET system in Belarus. VET graduates do not enjoy a significant labor market advantage over graduates with only a secondary certificate. Low returns to VET become zero when focusing on young workers with a VT diploma. These workers experience a larger wage reduction during periods of economic contraction, making VT a very ineffective and unattractive education option.

Low-income students are more likely to study in vocational schools. Therefore, having low returns to VET education is not only an inefficient use of public resources, it is also an outcome that has a larger negative impact for the wellbeing of disadvantaged students. From the equity point of view, the VET system should be providing the most effective education option capable of reverting preexisting inequalities. Our results show that what is happening is precisely the opposite, disadvantaged students have lower foundational skills (literacy and numeracy) when they enter the VET education system, and, based on the labor market returns, they have low or irrelevant professional competences when they graduate.

There is a long-term secular trend showing a lower demand for VET, particularly among vocational technical schools. This is a manifestation of students' preferences and labor market demands, both suggesting that the skills provided by the VET system in Belarus are not enough to secure a productive, well-paid job. The reduced demand in VT could be an opportunity to either reform this subsystem to make it closer to general secondary, merge it with the SSE subsystem, or stop considering it as a competitive education option.

The limitations of the VET system to promote inclusion and a more competitive labor force are not exclusive to Belarus, many other systems in the world face the same challenges. International experience showed that some policies have proven to be effective to address these challenges. This report provides five policy options, based on international practices relevant for the Belarus context and the characteristics of its VET system. Modernizing VET facilities, making sure that employers have a role in the definition of skills priorities, improving teaching policies, generating a public information system to inform candidates about the returns to VET and its different trades, and ensuring a minimum level of foundational skills among VET graduates would improve the effectiveness and equity of the Belarus education system. 


\section{REFERENCES}

Álvarez-Galván, José-Luis. 2014. OECD Reviews of Vocational Education and Training: A Skills Beyond School Review of Kazakhstan. Paris: Organisation for Economic Co-operation and Development. ??HYPERLINK "http://dx.doi.org/10.1787/9789264221826-en"ht.

BMZ (Federal Ministry for Economic Cooperation and Development of Germany). 2015. "Brand Ambassadors with Prospects for the Future: Development Partnership Establishes a Welding School in Pune." Retrieved from https://www.developpp.de/fileadmin/user_upload/publikationen/factsheet-deglorchdonbosco-en.pdf.

Brewer, Laura, and Paul Comyn. 2015. Integrating Core Work Skills into TVET Systems: Six Country Case Studies. Geneva: International Labor Office. Retrieved from https://www.ilo. org/wcmsp5/groups/public/---ed_emp/--ifp_skills/documents/publication/wcms_470726. pdf.

Buehren, Niklas, and Taylor Van Salisbury. 2017. "Female Enrollment in Male-Dominated Vocational Training Courses: Preferences and Prospects." Policy Brief 20, World Bank, Washington, DC.

Constant, Louay, Shelly Culbertson, Cathy Stasz, and Georges Vernez. 2014. Improving Technical Vocational Education and Training in the Kurdistan Region--Iraq. Santa Monica, CA: RAND.

Cort, Pia, Auli Härkönen, and Kristiina Volmari. 2004. PROFF - Professionalization of VET Teachers for the Future. Cedefop Panorama Series 104. Luxembourg: Office for Publications of the European Communities.

Chubrik, Shimanovich. 2013. Returns to Education and Evaluation of Human Capital in Belarus (in Russian). Belarus: IPM Research Center and Belarusian Institute for Strategic Studies. Retrieved from http://www.eng.research.by/webroot/delivery/files/wp2013r02.pdf.

ETF (European Training Foundation). (2020a). Belarus: Education, Training and Employment Developments 2020. Retrieved from https://www.etf.europa.eu/sites/default/files/document/Country\%20Fiche\%202020 \%20Belarus\%20-

\%20Education_\%20Training\%20and\%20Employment\%20Developments.pdf.

-- - . 2020b. Policies for Human Capital Development Belarus. An ETF Torino Process Assessment. Retrieved from https://www.etf.europa.eu/sites/default/files/202004/03_trpetf_assessment_2019_belarus_0.pdf.

- - . 2021. Listening to VET teachers and principals: Results of the ETF's international survey 2018. Retrieved from https://www.etf.europa.eu/en/publications-andresources/publications/listening-vocational-teachers-and-principals-results-etfs.

Fazekas, Mihály, and Simon Field. 2013. OECD Reviews of Vocational Education and Training: A Skills beyond School Review of Germany. Paris: OECD. http://dx.doi.org/10.1787/9789264202146-en. 
Kis, Viktoria. 2017. OECD Reviews of Vocational Education and Training: A Skills Beyond School Commentary on Viet Nam. Paris: OECD. https://www.oecd.org/education/skills-beyondschool/ASkillsBeyondSchoolCommentaryOnVietNam.pdf.

Kuczera, Małgorzata, and Simon Field. 2010. Learning for Jobs OECD Reviews of Vocational Education and Training: Options for China. Paris: OECD. https://www.oecd.org/china/45486493.pdf.

Melianova Ekatrerina, Suhas Parandekar, Harry Anthony Patrinos, and Artem Volgin. 2020. Returns to Education in the Russian Federation: Some New Estimates. Washington, DC: World Bank.

Ministry of Skill Development and Entrepreneurship of India. n.d. Sector Skill Councils.

National Statistical Committee of the Republic of Belarus. 2011-2019. Belarus Household Survey of Living Standards. https://www.belstat.gov.by/en/.

OECD (Organisation of Economic Co-operation and Development). 2010. Learning for Jobs. Synthesis Report of the OECD Reviews of Vocational Education and Training. Paris: OECD. http://www.oecd.org/education/skills-beyondschool/Learning\%20for\%20Jobs\%20book.pdf.

- - . 2014. Skills Beyond School: Synthesis Report. OECD Reviews of Vocational Education and Training. Paris: OECD. http//dx.doi.org/10.1787/9789264214682-en.

- - . 2018. Programme for International Student Assessment. Paris: OECD. https://www.oecd.org/pisa/.

Pastore, Francesco, and Alina Verashchagina. 2006. Private Returns to Human Capital Over Transition: A Case study of Belarus. Economics of Education Review 25 (1): 91-107.

Patrinos, Harry A. 2016. Estimating the Return to Schooling Using the Mincer Equation. IZA World of Labor.

World Bank. 2017. Nigeria - Lagos Eko Secondary Education Project. Washington, DC: World Bank.

-- - 2019. World Development Report 2019: The Changing Nature of Work. Washington, DC: World Bank. 
ANNEXES

Figure A1 Kernel Density Estimate of the Log Total Monthly Salary, 2011-2019

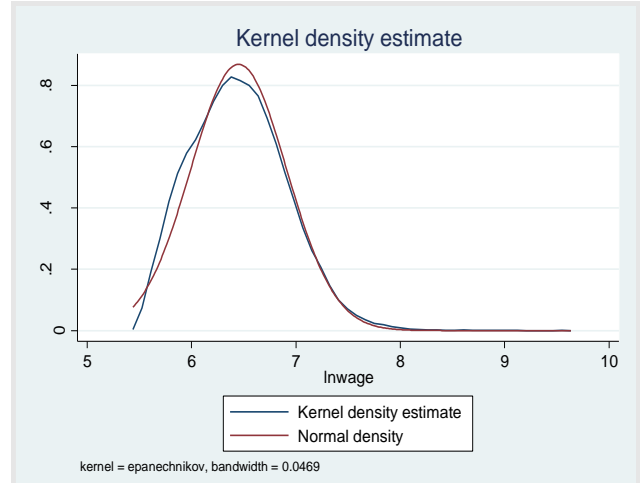

Source: Authors' calculations based on data from the National Statistical Committee of Belarus 2011-2019. 
Table A1 Returns to education in Belarus

\begin{tabular}{|c|c|c|c|c|c|c|c|c|c|}
\hline & Sample & $\begin{array}{c}\text { Youth (23- } \\
35)\end{array}$ & Sample & $\begin{array}{c}\text { Youth (23- } \\
35)\end{array}$ & $\begin{array}{l}\text { Higher } \\
\text { education }\end{array}$ & $\begin{array}{l}\text { VET sector } \\
\text { (as a } \\
\text { whole) }\end{array}$ & $\begin{array}{l}\text { Secondary } \\
\text { specialized }\end{array}$ & $\begin{array}{l}\text { Vocational } \\
\text { technical }\end{array}$ & $\begin{array}{l}\text { Secondary } \\
\text { education }\end{array}$ \\
\hline VARIABLES & Inwage & Inwage & Inwage & Inwage & & & & & \\
\hline \multicolumn{10}{|c|}{ Education: reference (secondary education) } \\
\hline \multirow[t]{2}{*}{ Higher education } & $0.371 * * *$ & $0.293 * * *$ & $0.370 * * *$ & $0.293 * * *$ & & & & & \\
\hline & $(0.00534)$ & $(0.0119)$ & $(0.00535)$ & $(0.0119)$ & & & & & \\
\hline \multirow[t]{2}{*}{ VET $^{6}$} & & & $0.101 * * *$ & $0.0747 * * *$ & & & & & \\
\hline & & & $(0.00477)$ & $(0.0113)$ & & & & & \\
\hline \multirow[t]{2}{*}{$\begin{array}{l}\text { Secondary } \\
\text { specialized }\end{array}$} & $0.128 * * *$ & $0.0877^{* * *}$ & & & & & & & \\
\hline & $(0.00503)$ & $(0.0118)$ & & & & & & & \\
\hline \multirow[t]{2}{*}{$\begin{array}{l}\text { Vocational } \\
\text { technical }\end{array}$} & $0.0450 * * *$ & $0.0461 * * *$ & & & & & & & \\
\hline & $(0.00584)$ & $(0.0137)$ & & & & & & & \\
\hline \multirow[t]{2}{*}{ Basic education } & $-0.0998 * * *$ & $-0.102 * * *$ & $-0.0990 * * *$ & $-0.101 * * *$ & & & & & \\
\hline & $(0.0172)$ & $(0.0326)$ & $(0.0173)$ & $(0.0326)$ & & & & & \\
\hline \multirow[t]{2}{*}{ age } & $0.0485 * * *$ & $0.0892 * * *$ & $0.0484 * * *$ & $0.0889 * * *$ & $0.0727 * * *$ & $0.0455^{* * *}$ & $0.0482 * * *$ & $0.0419 * * *$ & $0.0340 * * *$ \\
\hline & $(0.00136)$ & $(0.0253)$ & $(0.00136)$ & $(0.0253)$ & $(0.00320)$ & $(0.00177)$ & $(0.00217)$ & $(0.00301)$ & $(0.00286)$ \\
\hline \multirow[t]{2}{*}{ agesq } & $\begin{array}{c}- \\
0.00059 * * *\end{array}$ & $\begin{array}{c}- \\
0.0012 * * *\end{array}$ & $\begin{array}{c}- \\
0.00059 * * *\end{array}$ & $\begin{array}{c}- \\
0.0012 * * *\end{array}$ & $\begin{array}{c}- \\
0.00085^{* * *}\end{array}$ & $\begin{array}{c}- \\
0.00056 * * *\end{array}$ & $\begin{array}{c}- \\
0.00059 * * *\end{array}$ & $\begin{array}{c}- \\
0.00053 * * *\end{array}$ & $\begin{array}{c}- \\
0.00043 * * *\end{array}$ \\
\hline & $(1.63 e-05)$ & $(0.000431)$ & $(1.63 e-05)$ & $(0.000431)$ & (3.79e-05) & $(2.13 e-05)$ & (2.61e-05) & (3.63e-05) & (3.41e-05) \\
\hline \multirow[t]{2}{*}{ sex (male) } & $0.262^{* * *}$ & $0.356 * * *$ & $0.256^{* * *}$ & $0.355^{* * *}$ & $0.247^{* * *}$ & $0.259 * * *$ & $0.260 * * *$ & $0.299 * * *$ & $0.266 * * *$ \\
\hline & $(0.00349)$ & $(0.00749)$ & $(0.00348)$ & $(0.00747)$ & $(0.00726)$ & $(0.00457)$ & $(0.00561)$ & $(0.00807)$ & $(0.00780)$ \\
\hline \multicolumn{10}{|c|}{ Region: reference (Brest oblast) } \\
\hline \multirow[t]{2}{*}{ Vitebsk oblast } & $0.0122^{*}$ & -0.00964 & $0.0109 *$ & -0.0110 & 0.0110 & $0.0189 * *$ & $0.0201^{* *}$ & $0.0278^{*}$ & -0.00588 \\
\hline & $(0.00644)$ & $(0.0139)$ & $(0.00645)$ & $(0.0139)$ & $(0.0141)$ & $(0.00837)$ & $(0.00997)$ & $(0.0152)$ & $(0.0142)$ \\
\hline
\end{tabular}

\footnotetext{
${ }^{6}$ VET is a variable, which includes both secondary specialized education and vocational school graduates. In other specifications they are analyzed separately
} 


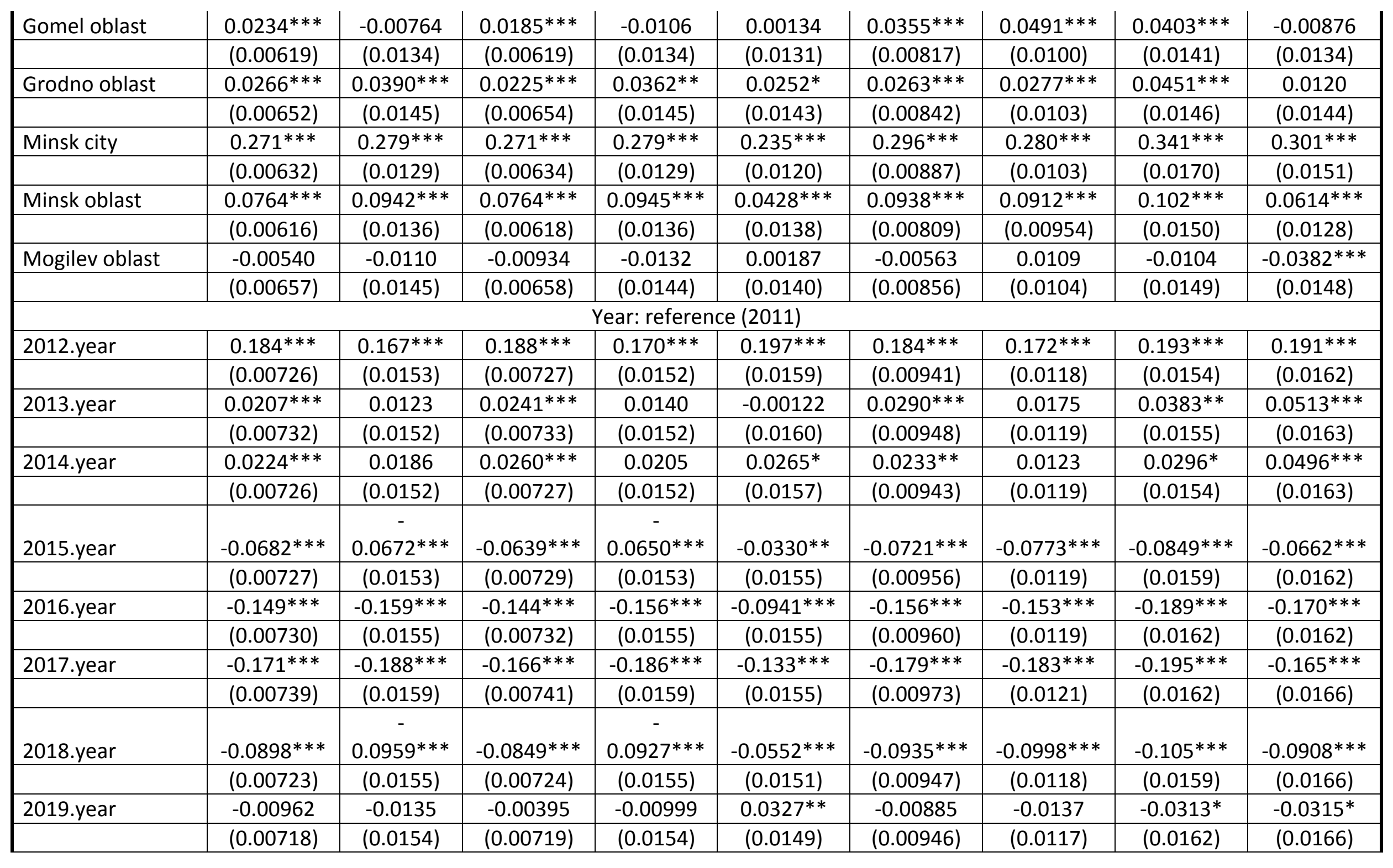




\begin{tabular}{|c|c|c|c|c|c|c|c|c|c|}
\hline Constant & $5.210 * * *$ & $4.584 * * *$ & $5.215^{* * *}$ & $4.589 * * *$ & $5.050 * * *$ & $5.381 * * *$ & $5.349 * * *$ & $5.386 * * *$ & $5.522 * * *$ \\
\hline & $(0.0285)$ & $(0.368)$ & $(0.0286)$ & $(0.368)$ & $(0.0666)$ & $(0.0369)$ & $(0.0453)$ & $(0.0628)$ & $(0.0598)$ \\
\hline Observations & 52,534 & 12,192 & 52,534 & 12,192 & 14,720 & 28,199 & 19,084 & 9,115 & 9,061 \\
\hline
\end{tabular}

Standard errors in parentheses, ${ }^{* * *} p<0.01,{ }^{* *} p<0.05,{ }^{*} p<0.1$

Source: Authors' calculations based on data from the National Statistical Committee of Belarus 2011-2019.

Table A2 Estimates of returns to education, by year (2011-2019)

\begin{tabular}{|c|c|c|c|c|c|c|c|c|c|}
\hline & 2011 & 2012 & 2013 & 2014 & 2015 & 2016 & 2017 & 2018 & 2019 \\
\hline VARIABLES & Inwage & Inwage & Inwage & Inwage & Inwage & Inwage & Inwage & Inwage & Inwage \\
\hline \multicolumn{10}{|c|}{ Education: reference (secondary education) } \\
\hline \multirow[t]{2}{*}{ Higher education } & $0.349 * * *$ & $0.354 * * *$ & $0.313 * * *$ & $0.336 * * *$ & $0.369 * * *$ & $0.419 * * *$ & $0.383 * * *$ & $0.388 * * *$ & $0.416 * * *$ \\
\hline & $(0.0153)$ & $(0.0165)$ & $(0.0173)$ & $(0.0164)$ & $(0.0156)$ & $(0.0155)$ & $(0.0160)$ & $(0.0159)$ & (0.0158) \\
\hline \multirow[t]{2}{*}{ Secondary specialized } & $0.134 * * *$ & $0.111^{* * *}$ & $0.111^{* * *}$ & $0.107 * * *$ & $0.124 * * *$ & $0.154 * * *$ & $0.122 * * *$ & $0.129 * * *$ & $0.160 * * *$ \\
\hline & $(0.0143)$ & $(0.0152)$ & $(0.0159)$ & $(0.0153)$ & $(0.0147)$ & $(0.0146)$ & $(0.0153)$ & $(0.0152)$ & $(0.0152)$ \\
\hline \multirow[t]{2}{*}{ Vocational technical } & $0.0569 * * *$ & $0.0501 * * *$ & $0.0414^{* *}$ & $0.0336^{*}$ & $0.0395 * *$ & $0.0428 * *$ & $0.0306^{*}$ & $0.0437 * *$ & $0.0632 * * *$ \\
\hline & $(0.0154)$ & $(0.0176)$ & $(0.0182)$ & $(0.0176)$ & $(0.0174)$ & $(0.0175)$ & $(0.0180)$ & $(0.0179)$ & $(0.0183)$ \\
\hline \multirow[t]{2}{*}{ Basic education } & -0.0527 & $-0.0937^{* *}$ & $-0.0902^{*}$ & $-0.133^{* *}$ & $-0.144^{* * *}$ & -0.0838 & -0.0762 & $-0.112^{*}$ & $-0.187^{* * *}$ \\
\hline & $(0.0373)$ & $(0.0448)$ & $(0.0519)$ & $(0.0521)$ & $(0.0551)$ & $(0.0586)$ & $(0.0648)$ & $(0.0590)$ & $(0.0589)$ \\
\hline \multirow[t]{2}{*}{ age } & $0.0410 * * *$ & $0.0582 * * *$ & $0.0457^{* * *}$ & $0.0533 * * *$ & $0.0509 * * *$ & $0.0478 * * *$ & $0.0456 * * *$ & $0.0464 * * *$ & $0.0501 * * *$ \\
\hline & $(0.00387)$ & $(0.00399)$ & $(0.00428)$ & $(0.00406)$ & $(0.00402)$ & $(0.00414)$ & $(0.00418)$ & $(0.00413)$ & $(0.00421)$ \\
\hline \multirow[t]{2}{*}{ agesq } & $-0.000508 * * *$ & $-0.000712^{* * *}$ & $-0.000556 * * *$ & $-0.000648 * * *$ & $-0.000625 * * *$ & $-0.000583 * * *$ & $-0.000552 * * *$ & $-0.000565 * * *$ & $\begin{array}{c}- \\
0.000617^{* * *}\end{array}$ \\
\hline & $(4.72 \mathrm{e}-05)$ & $(4.84 \mathrm{e}-05)$ & $(5.16 e-05)$ & $(4.86 e-05)$ & $(4.81 \mathrm{e}-05)$ & $(4.93 e-05)$ & $(4.96 \mathrm{e}-05)$ & $(4.89 \mathrm{e}-05)$ & $(4.96 e-05)$ \\
\hline \multirow[t]{2}{*}{ sex (male) } & $0.239 * * *$ & $0.248 * * *$ & $0.301 * * *$ & $0.302 * * *$ & $0.252 * * *$ & $0.240 * * *$ & $0.251 * * *$ & $0.262 * * *$ & $0.269 * * *$ \\
\hline & $(0.00980)$ & $(0.0107)$ & $(0.0111)$ & $(0.0106)$ & $(0.0104)$ & $(0.0104)$ & $(0.0106)$ & $(0.0103)$ & $(0.0102)$ \\
\hline \multicolumn{10}{|c|}{ Region: reference (Brest oblast) } \\
\hline \multirow[t]{2}{*}{ Vitebsk oblast } & $0.0458^{* *}$ & 0.0224 & 0.0282 & $0.0403^{* *}$ & 0.0134 & 0.00294 & -0.0139 & $-8.91 e-05$ & -0.0309 \\
\hline & $(0.0179)$ & $(0.0197)$ & $(0.0198)$ & $(0.0196)$ & $(0.0193)$ & $(0.0193)$ & $(0.0197)$ & $(0.0191)$ & $(0.0192)$ \\
\hline \multirow[t]{2}{*}{ Gomel oblast } & $0.0638 * * *$ & 0.0206 & $0.0649 * * *$ & $0.0425 * *$ & $0.0670 * * *$ & 0.0135 & -0.00688 & -0.0214 & -0.0292 \\
\hline & $(0.0173)$ & $(0.0190)$ & $(0.0198)$ & $(0.0187)$ & $(0.0185)$ & $(0.0183)$ & $(0.0185)$ & $(0.0184)$ & $(0.0184)$ \\
\hline \multirow[t]{2}{*}{ Grodno oblast } & 0.0216 & 0.0129 & $0.0557 * * *$ & 0.0312 & $0.0384 * *$ & 0.0213 & 0.00320 & 0.0236 & 0.0224 \\
\hline & $(0.0182)$ & $(0.0197)$ & $(0.0204)$ & $(0.0198)$ & $(0.0195)$ & $(0.0197)$ & $(0.0201)$ & $(0.0193)$ & $(0.0193)$ \\
\hline \multirow[t]{2}{*}{ Minsk city } & $0.260 * * *$ & $0.210 * * *$ & $0.238 * * *$ & $0.262 * * *$ & $0.352^{* * *}$ & $0.305^{* * *}$ & $0.279 * * *$ & $0.262^{* * *}$ & $0.268 * * *$ \\
\hline & $(0.0175)$ & $(0.0191)$ & $(0.0196)$ & $(0.0192)$ & $(0.0189)$ & $(0.0188)$ & $(0.0195)$ & $(0.0190)$ & $(0.0189)$ \\
\hline
\end{tabular}




\begin{tabular}{|c|c|c|c|c|c|c|c|c|c|}
\hline Minsk oblast & $0.0771 * * *$ & $0.0839 * * *$ & $0.125^{* * *}$ & $0.117^{* * *}$ & $0.0985^{* * *}$ & $0.0850 * * *$ & $0.0445^{* *}$ & 0.0181 & $0.0356 *$ \\
\hline & $(0.0171)$ & $(0.0185)$ & $(0.0193)$ & $(0.0185)$ & $(0.0186)$ & $(0.0182)$ & $(0.0188)$ & $(0.0186)$ & $(0.0184)$ \\
\hline \multirow[t]{2}{*}{ Mogilev oblast } & 0.0238 & -0.00940 & -0.00887 & 0.0329 & 0.0180 & 0.00948 & -0.0203 & -0.0307 & $-0.0574 * * *$ \\
\hline & $(0.0187)$ & $(0.0201)$ & $(0.0211)$ & $(0.0202)$ & (0.0198) & (0.0197) & (0.0198) & $(0.0189)$ & $(0.0191)$ \\
\hline \multirow[t]{2}{*}{ Constant } & $5.364 * * *$ & $5.235 * * *$ & $5.268 * * *$ & $5.115 * * *$ & $5.084 * * *$ & $5.054 * * *$ & $5.107 * * *$ & $5.175 * * *$ & $5.176 * * *$ \\
\hline & $(0.0781)$ & $(0.0799)$ & $(0.0867)$ & $(0.0834)$ & $(0.0830)$ & $(0.0860)$ & $(0.0872)$ & $(0.0863)$ & $(0.0886)$ \\
\hline Observations & 5824 & 5875 & 5685 & 5874 & 5846 & 5752 & 5492 & 6003 & 6183 \\
\hline R-squared & 0.217 & 0.213 & 0.204 & 0.230 & 0.262 & 0.266 & 0.249 & 0.251 & 0.275 \\
\hline
\end{tabular}

Standard errors in parentheses, $* * * p<0.01, * * p<0.05, * p<0.1$

Source: Authors' calculations based on data from the National Statistical Committee of Belarus 2011-2019.

Table A3. Estimates of returns to education in Belarus, by region

\begin{tabular}{|c|c|c|c|c|c|c|c|}
\hline & Brest oblast & $\begin{array}{l}\text { Vitebsk } \\
\text { oblast }\end{array}$ & $\begin{array}{l}\text { Gomel } \\
\text { oblast }\end{array}$ & $\begin{array}{l}\text { Grodno } \\
\text { oblast }\end{array}$ & Minsk city & Minsk oblast & $\begin{array}{l}\text { Mogilev } \\
\text { oblast }\end{array}$ \\
\hline VARIABLES & Inwage & Inwage & Inwage & Inwage & Inwage & Inwage & Inwage \\
\hline \multicolumn{8}{|c|}{ Education: reference (secondary education) } \\
\hline \multirow[t]{2}{*}{ Higher education } & $0.374 * * *$ & $0.386 * * *$ & $0.398 * * *$ & $0.392 * * *$ & $0.278 * * *$ & $0.361 * * *$ & $0.414 * * *$ \\
\hline & $(0.0128)$ & $(0.0145)$ & $(0.0135)$ & $(0.0148)$ & $(0.0164)$ & $(0.0129)$ & $(0.0148)$ \\
\hline \multirow[t]{2}{*}{ SSE } & $0.106 * * *$ & $0.126 * * *$ & $0.167 * * *$ & $0.123 * * *$ & $0.0662 * * *$ & $0.136 * * *$ & $0.152 * * *$ \\
\hline & $(0.0118)$ & $(0.0132)$ & $(0.0129)$ & $(0.0136)$ & $(0.0171)$ & $(0.0114)$ & $(0.0140)$ \\
\hline \multirow[t]{2}{*}{ VT } & 0.0233 & $0.0477 * * *$ & $0.0649 * * *$ & $0.0549 * * *$ & 0.0315 & $0.0547 * * *$ & $0.0402 * * *$ \\
\hline & $(0.0145)$ & $(0.0153)$ & $(0.0141)$ & $(0.0150)$ & $(0.0213)$ & $(0.0141)$ & $(0.0154)$ \\
\hline \multirow[t]{2}{*}{ Basic education } & -0.0738 & $-0.160 * * *$ & $-0.109 * * *$ & -0.0709 & $-0.149 * *$ & -0.0130 & $-0.0900 *$ \\
\hline & $(0.0485)$ & $(0.0367)$ & $(0.0374)$ & $(0.0606)$ & $(0.0744)$ & $(0.0381)$ & $(0.0472)$ \\
\hline \multirow[t]{2}{*}{ age } & $0.0382 * * *$ & $0.0486 * * *$ & $0.0475 * * *$ & $0.0441^{* * *}$ & $0.0655^{* * *}$ & $0.0427 * * *$ & $0.0554 * * *$ \\
\hline & $(0.00346)$ & $(0.00363)$ & $(0.00347)$ & $(0.00370)$ & $(0.00385)$ & $(0.00333)$ & $(0.00377)$ \\
\hline \multirow[t]{2}{*}{ agesq } & $\begin{array}{c}- \\
0.000476 * * *\end{array}$ & $\begin{array}{c}- \\
0.000594 * * *\end{array}$ & $\begin{array}{c}- \\
0.000563 * * *\end{array}$ & $\begin{array}{c}- \\
0.000540 * * *\end{array}$ & $\begin{array}{c}- \\
0.000801^{* * *}\end{array}$ & $\begin{array}{c}- \\
0.000539 * * *\end{array}$ & $\begin{array}{c}- \\
0.000670 * * *\end{array}$ \\
\hline & $(4.14 \mathrm{e}-05)$ & $(4.33 e-05)$ & $(4.16 \mathrm{e}-05)$ & $(4.43 e-05)$ & (4.66e-05) & (3.97e-05) & $(4.48 \mathrm{e}-05)$ \\
\hline \multirow[t]{2}{*}{ sex } & $0.252 * * *$ & $0.227 * * *$ & $0.285^{* * *}$ & $0.264 * * *$ & $0.291 * * *$ & $0.276 * * *$ & $0.233 * * *$ \\
\hline & $(0.00864)$ & $(0.00921)$ & $(0.00890)$ & $(0.00940)$ & $(0.0103)$ & $(0.00860)$ & $(0.00936)$ \\
\hline
\end{tabular}




\begin{tabular}{|l|c|c|c|c|c|c|c|} 
Constant & $5.429 * * *$ & $5.258^{* * *}$ & $5.216^{* * *}$ & $5.297 * * *$ & $5.175^{* * *}$ & $5.407^{* * *}$ & $5.073^{* * *}$ \\
\hline & $(0.0719)$ & $(0.0750)$ & $(0.0716)$ & $(0.0771)$ & $(0.0765)$ & $(0.0693)$ & $(0.0787)$ \\
\hline Observations & 7,896 & 7,034 & 8,246 & 6,697 & 7,776 & 8,350 & 6,535 \\
\hline R-squared & 0.233 & 0.233 & 0.240 & 0.240 & 0.196 & 0.242 & 0.254 \\
\hline
\end{tabular}

Notes: Standard errors in parentheses, ${ }^{* * *} p<0.01,{ }^{* *} p<0.05,{ }^{*} p<0.1$; year effects are included in the regression

Source: Authors' calculations based on data from the National Statistical Committee of Belarus 2011-2019. 